\title{
Characterization of Gold Mining Waste for Carbon Sequestration and Utilization as Supplementary Cementitious Material
}

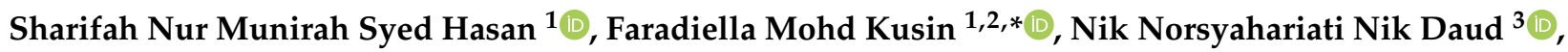 \\ Muhammad Anwar Saadon ${ }^{1}$, Ferdaus Mohamat-Yusuff ${ }^{1}$ and Zulfa Hanan Ash'aari ${ }^{1}$ \\ 1 Department of Environment, Faculty of Forestry and Environment, Universiti Putra Malaysia, \\ Serdang 43400 UPM, Selangor, Malaysia; muniraleeshara@gmail.com (S.N.M.S.H.); \\ anwarmyth11@gmail.com (M.A.S.); ferdius@upm.edu.my (F.M.-Y.); zulfa@upm.edu.my (Z.H.A.) \\ 2 Institute of Tropical Forestry and Forest Products (INTROP), Universiti Putra Malaysia, \\ Serdang 43400 UPM, Selangor, Malaysia \\ 3 Department of Civil Engineering, Faculty of Engineering, Universiti Putra Malaysia, \\ Serdang 43400 UPM, Selangor, Malaysia; niknor@upm.edu.my \\ * Correspondence: faradiella@upm.edu.my; Tel.: +60-1-0366-6160
}

check for updates

Citation: Syed Hasan, S.N.M.; Mohd Kusin, F.; Nik Daud, N.N.; Saadon, M.A.; Mohamat-Yusuff, F.; Ash'aari, Z.H. Characterization of Gold Mining Waste for Carbon Sequestration and Utilization as Supplementary Cementitious Material. Processes 2021 9, 1384. https://doi.org/10.3390/ pr9081384

Academic Editors: Federica Raganati and Paola Ammendola

Received: 23 June 2021

Accepted: 2 August 2021

Published: 9 August 2021

Publisher's Note: MDPI stays neutral with regard to jurisdictional claims in published maps and institutional affiliations.

Copyright: (c) 2021 by the authors. Licensee MDPI, Basel, Switzerland. This article is an open access article distributed under the terms and conditions of the Creative Commons Attribution (CC BY) license (https:// creativecommons.org/licenses/by/ $4.0 /)$

\begin{abstract}
This study aims to identify the potential of gold mining waste for $\mathrm{CO}_{2}$ sequestration and its utilization for carbon storage in cementitious material. Samples of mine waste were identified from a gold mine for mineralogical and chemical composition analysis using $X$-ray diffractogram and scanning electron microscopy with energy-dispersive X-ray. Mine waste was utilized in a brickmaking process as supplementary cementitious material and as an agent for $\mathrm{CO}_{2}$ capture and storage in bricks. Carbonation curing was incorporated in brick fabrication to estimate $\mathrm{CO}_{2}$ uptake of the brick product. Results indicated that the mine wastes were composed of silicate minerals essential for mineral carbonation such as muscovite and illite (major) and chlorite-serpentine, aerinite, albite and stilpnomelane (moderate/minor phases). The mine wastes were identified as belonging to the highly pozzolanic category, which has a great role in improving the strength properties of brick products. Carbonated minerals served as an additional binder that increased the strength of the product. $\mathrm{CO}_{2}$ uptake of the product was between $0.24 \%$ and $0.57 \%$ for bricks containing $40-60 \%$ of gold mine waste, corresponding to $7.2-17.1 \mathrm{~g} \mathrm{CO}_{2} /$ brick. Greater performance in terms of compressive strength and water adsorption was observed for bricks with $3 \mathrm{~h}$ carbonation curing. The carbonation product was evidenced by strong peaks of calcite and reduced peaks for calcium hydroxide from XRD analysis and was supported by a densified and crystalline microstructure of materials. It has been demonstrated that gold mine waste is a potential feedstock for mineral carbonation, and its utilization for permanent carbon storage in brick making is in line with the concept of CCUS for environmental sustainability.
\end{abstract}

Keywords: mine waste; minerals; carbon sequestration; carbon capture and storage (CCS); carbon capture utilization (CCU); cementitious material; climate action

\section{Introduction}

It is clear under the United Nations Sustainable Development Goals (SDG) 13, Climate Action, that climate change is the greatest challenge to sustainable development and requires urgent action to combat it and its impacts. Climate change is intensified by the introduction of greenhouse gas (GHG) emissions into the atmosphere through various anthropogenic and natural processes. Global emissions of carbon dioxide $\left(\mathrm{CO}_{2}\right)$ have been increasing mainly due to industrialization, associated with the combustion of fossil fuel, cement and lime industries that have inflicted the earth [1]. According to International Energy Agency (IEA), 13\% reduction in cumulative $\mathrm{CO}_{2}$ emissions is required by 2050, which is around 6 billion tons of $\mathrm{CO}_{2}$ removal per year [2]. Malaysia has committed to reducing $45 \%$ of its GHG emissions by 2030 , and its aspiration to achieve net zero carbon 
emissions by 2050 has been initiated. It has been targeted for $\mathrm{CO}_{2}$ emissions to reach net zero between 2040 and 2060 [3,4].

The impact of climate change due to anthropogenic emissions of $\mathrm{CO}_{2}$ can be reduced via the capture of $\mathrm{CO}_{2}$ in geological reservoirs. Specifically, among the technologies that are available to stabilize and reduce atmospheric $\mathrm{CO}_{2}$ emissions from large-scale usage of fossil fuel is one known as carbon capture and storage (CCS) or carbon sequestration [5-8]. Geological carbon sequestration is a process of removing $\mathrm{CO}_{2}$ from the atmosphere and storing it in geological formations for a long period of time $[9,10]$. By using sequestration technology, it is possible to capture the carbon and fix it into solids so that it can be disposed of more efficiently and/or used as a secondary product for commercial value [11-13]. Therefore, a feasible and reliable technology should be adopted to reduce $\mathrm{CO}_{2}$ emissions in the long run such as CCS technology. However, carbon capture, utilization and storage (CCUS) is a relatively new concept that synergizes utilization with widely known CCS methods. In a broader context, CCUS prevents $\mathrm{CO}_{2}$ from being released into the atmosphere by capturing it and either using it or injecting it into geological formations for permanent storage [14]. Included in this concept is the utilization of captured $\mathrm{CO}_{2}$ as a feedstock for making products in which $\mathrm{CO}_{2}$ is permanently stored [8]. Reaction of $\mathrm{CO}_{2}$ with mineral systems, i.e., mineral carbonation or carbon mineralization, has been the key to mineralization technology, which is a method of carbon dioxide removal in the category of CCUS technology $[1,7,15]$. Mineral carbonation is a process that helps sequester $\mathrm{CO}_{2}$ permanently in stable carbonates, which can prevent the release of $\mathrm{CO}_{2}$ back into the atmosphere $[9,16]$. Silicate-containing minerals such as magnesium, calcium and iron silicates are commonly utilized, upon which reactions with $\mathrm{CO}_{2}$ can form stable carbonate minerals.

The mining industry is among the industrial sectors that contribute to the emission of greenhouse gases, particularly $\mathrm{CO}_{2}$. Mining operations have resulted in massive production of mining waste, mill tailings and materials related to waste refinery. Mining waste is considered as materials that do not contain ore materials or minerals, or those in which the concentration of the materials is sub-economic $[17,18]$. Mining waste can be utilized for permanent storage of carbon dioxide, and it has potential for economic benefits in providing a practical solution to mitigating carbon emissions [19-21]. Silicate rocks that contain the desired amount of $\mathrm{Mg}$ and $\mathrm{Ca}$ have been targeted for mineral carbonation of mining waste [22]. However, Mg-silicate minerals are preferable compared to Ca-silicate minerals as they contain more reactive minerals per ton of rocks and are more readily available around the world [23-26]. This silicate mineral that can be found in many ore deposits in the environment is suitable as feedstock for mineral carbonation [27-29]. $\mathrm{Mg}$-silicates are ideal minerals as adsorbents for the $\mathrm{CO}_{2}$ sequestration process because of their low solubility of alkaline earth minerals, which makes them stable on a geological timescale $[1,30,31]$. While the minerals were often mined as the targeted minerals for carbonation, they were found in mine waste materials as the by-product of mining processes, thereby indicating the potential utilization of mine waste for carbon sequestration [32]. For instance, the mineral carbonation reaction of $\mathrm{Mg}$-silicates are given in Equations (1) and (2). Similarly important are Fe-silicate or -oxide minerals, which have been found to be beneficial for mineral carbonation [33-35]. The role of these $\mathrm{Mg}$-Ca-Fe-bearing minerals has been studied and is most widely associated with various factors that can influence the degree of carbonation [33-36].

$$
\begin{gathered}
\mathrm{Mg}_{2} \mathrm{SiO}_{4}(\mathrm{~s})+\mathrm{CO}_{2}(\mathrm{~g}) \rightarrow \mathrm{MgCO}_{3}(\mathrm{~s})+\mathrm{SiO}_{2}(\mathrm{~s}) \\
\mathrm{Mg}_{2} \mathrm{Si}_{2} \mathrm{O}_{5}(\mathrm{OH})_{4}(\mathrm{~s})+\mathrm{CO}_{2}(\mathrm{~g}) \rightarrow \mathrm{MgCO}_{3}(\mathrm{~s})+\mathrm{SiO}_{2}(\mathrm{~s})+\mathrm{H}_{2} \mathrm{O}(\mathrm{L} / \mathrm{g})
\end{gathered}
$$

The cement industry is another one of the main sources of anthropogenic $\mathrm{CO}_{2}$, accounting for about $8 \%$ of global emissions [14]. Among the directions of this industry in mitigating industrial $\mathrm{CO}_{2}$ emissions, the deployment of CCUS technologies to achieve the $\mathrm{CO}_{2}$ emissions reduction target by 2050 has been emphasized. The global effort to 
reduce $\mathrm{CO}_{2}$ emissions reduction in the cement industry aims to identify the impact of co-processing, the efficiency of clinker production, implementation of CCUS technology, the impact of clinker substitutes and alternative binders in concrete, low-carbon concrete technologies, and re-carbonation [37-39]. Notwithstanding this, it has been noted that about $10-40 \%$ of $\mathrm{CO}_{2}$ emissions associated with concrete products may be offset by gradual reabsorption of atmospheric $\mathrm{CO}_{2}$ by the exothermic carbonation of hydrated cement $[17,40]$. The roles of CCUS technology using mineral carbonation in sequestering carbon for concrete and cement industries have been studied earlier, including carbonation applications in the manufacture of cement-based products such as concrete, bricks and blocks [41-46]. It has been estimated that mining wastes such as gold and limestone mine wastes have the ability to store between $7 \%$ and $61 \%$ of $\mathrm{CO}_{2}$ in brick products, suggesting that the mineral carbonation process using sedimentary mining waste is likely to have an economic benefit in the future $[47,48]$. Therefore, it is the aim of this study to identify the potential of gold mining waste for carbon sequestration and its utilization for long-term carbon storage in cementitious products. The mining waste characterizations were first identified in view of its mineralogical and chemical composition before exploring the performance of the product that integrates mineral carbonation through its fabrication process.

\section{Materials and Methods}

\subsection{Mine Waste Sampling}

Gold mine wastes were recovered from a gold mine in the state of Pahang, Peninsular Malaysia. Samples of gold mine waste were identified from waste dump, stockpile and mine tailings in the forms of waste rocks, soil, sediment and sludge. Descriptions of the sampling location and types of samples are given in Table 1. The sampling strategy was based on previous geological information and lithology of the mine rock, where the parent rock hosting Selinsing gold mine is primarily made of Carboniferous to Triassic tuffaceous rock $[49,50]$. Waste rock samples were collected at the waste dump and stockpile area (high-, low- and super-low-grade ores). The samples were taken at the drill hole mine of the waste dump and stockpiles, which consist of waste rock substances. Samples of soil, sediment and sludge were collected at an equal surface area of about $15-20 \mathrm{~cm}$ depth [51]. The samples were collected using stainless steel trowel and were kept in polythene bags. Soil samples were air-dried, whereas sediment and sludge were oven-dried prior to sieving. A total weight of $16 \mathrm{~kg}$ of waste rocks, $18 \mathrm{~kg}$ of soil and $5 \mathrm{~kg}$ of sludge and sediment samples were collected from the site and composite samples were obtained.

Table 1. Description of gold mine waste samples.

\begin{tabular}{|c|c|c|}
\hline Sampling Location & Type of Sample & Characteristics \\
\hline Waste dump (WD) & Waste rock soil & $\begin{array}{l}\text { Sedimentary rock, aragonite, volcanic. Highly silicate clay, } \\
\text { argillite, kaolinite, serenite, medium to fine size, highly oxidized }\end{array}$ \\
\hline $\begin{array}{c}\text { Stockpile } \\
\text { - High-grade (HS) } \\
\text { - Low-grade (LS) } \\
\text { - Super-low-grade (SLS) }\end{array}$ & Waste rock soil & Phyllite, conglomerate \\
\hline $\begin{array}{l}\text { Mine tailings } \\
\text { - Sediment (SED) } \\
\text { - Sludge (SLU) }\end{array}$ & Sediment sludge & Waste from tailing storage facility \\
\hline
\end{tabular}

\subsection{Mineralogical Analysis}

The mine waste samples were subjected to X-ray diffraction (XRD) for mineralogical identification of the major and minor mineral phases. Waste rock samples were first crushed and ground into fine particles and sieved to $1 \mathrm{~mm}$ size fraction using particle sieves (nonoriented samples). For soils and sediments, a small number of clay samples from pipette analysis were used (oriented samples). Approximately $1 \pm 0.5 \mathrm{~g}$ of the fine powder samples were mounted on a $2.5 \mathrm{~cm}$ diameter specimen holder before being attached to an X-ray 
diffractometer. An XRD instrument, Bruker D8 Advanced X-ray diffractometer, counting for $0.2 \mathrm{~s}$ per step of scattering angle between 5 and $50^{\circ}$, at a rate of $1^{\circ}$ per min, was used, with a detection limit of 1 to $2 \%$. The identification of minerals was done using data from the XRD analysis refined with Diffrac AT EVA software and crystallography open database.

\subsection{Physicochemical Analysis}

Particle size analysis was performed to analyze the fractional particle sizes of the mine waste samples. Prior to the analysis, the samples were dried at room temperature for approximately $24 \mathrm{~h}$. The pipette method was used to determine the percentage of sand, silt and clay fractions of the soil samples. In the analysis, only samples smaller than $2 \mathrm{~mm}$ were used to remove colloid coatings on soil, sediment and sludge samples to achieve complete dispersion, which is the key to accurate mechanical analysis [52]. In order to obtain the desired particle sizes, a particle sieve was used to manually sieve the samples until $<2 \mathrm{~mm}$ fraction was obtained, after which it underwent pipette analysis. Samples were pre-treated using $100 \mathrm{~mL}$ of hydrogen peroxide $\left(\mathrm{H}_{2} \mathrm{O}_{2}\right)$ and were left overnight to remove organic matter. Using the pipette method, the samples subjected to a few steps for separation of silt and clay composition from the sand and further separation of silt and clay components. The sedimentation technique was applied to the supernatant liquid after heating on a hot plate, and samples were subjected to sieving with a $50 \mu \mathrm{m}$ sieve to separate silt and clay suspension from the sand. The sample suspension was pipetted at a depth of $10 \mathrm{~cm}$ along with the aliquot where the clay fraction was obtained. The clay fraction was retained for mineral composition analysis using $\mathrm{X}$-ray diffraction. The particle size distribution was calculated as the percentage (\%) of soil fractions following the soil classification schemes of the United States Department of Agriculture (USDA). The soil is classified as clay $(<2 \mu \mathrm{m})$, silt $(2-50 \mu \mathrm{m})$ and sand $(>50 \mu \mathrm{m})$. Scanning electron microscopy with energy-dispersive $X$-ray (SEM-EDS) analysis was performed to determine the chemical composition of the samples. An SEM-EDS instrument, model Hitachi SU3500 was used with a detection limit of $0.1 \%$. Approximately $1 \pm 0.5 \mathrm{~g}$ of homogeneous fine powder samples for phase determination were applied to the EDX instrument. Through SEM analysis, surface morphological structures of the mining waste were observed. EDS spectrum with peaks corresponding to each element in the sample were identified, and data are presented as the percentage by weight, wt.\% of the major oxides.

\subsection{Brick Fabrication for Carbon Capture and Storage}

To investigate the potential utilization of the mine waste as supplementary cementitious material, sand bricks were partially fabricated with the mine waste. The gold mine wastes were incorporated as supplementary aggregates in the fabrication of bricks with the proportion varying between 40 and $60 \%$ by weight as given in Table 2 . Ordinary Portland cement (OPC) was used as the binder, while sand was used as aggregates in the design mix to improve the mechanical strength of the mortar [46]. In the normal brick (control), the proportion of OPC was set at $40 \%$ by weight with a mix design of 2:3 [46]. For gold mine waste bricks, the percentage of OPC used was reduced to $20-30 \%$ by weight (partial replacement for cement), while the sand was varied between 20 and $30 \%$ by weight as with the addition of gold mine waste. The water-to-cement ratio was kept at 0.5 . The bricks were fabricated with a dimension of $215 \times 102.5 \times 65 \mathrm{~mm}$ following the brick specifications of Malaysian Standard MS 76: 1972 [53] using a steel mold. After demolding, the curing process was performed for 21 days by maintaining the moisture until the samples attained the required strength. The cement hydration was maintained by spraying water over the concrete surface during the curing process. For each type of brick, replicate samples were prepared for corresponding analyses. Note that carbonation curing was incorporated during the curing process after $24 \mathrm{~h}$ of demolding, and the details are provided in the following section. The bricks were then subjected to compressive strength analysis and water absorption test to determine their compliance with standard criteria of brick specifications according to Malaysian Standards MS 76: 1972. 
Table 2. Mixture proportion of gold mine waste bricks.

\begin{tabular}{ccccc}
\hline Brick Type & Mix Design & Cement (\%) * & Sand (\%) * & $\begin{array}{c}\text { Gold Mine } \\
\text { Waste (\%) }\end{array}$ \\
\hline Normal brick (control) & $2: 3$ & 40 & 60 & - \\
GMW40 & $1.5: 1.5: 2$ & 30 & 30 & 40 \\
GMW50 & $1.5: 1: 2.5$ & 30 & 20 & 50 \\
GMW60 & $1: 1: 3$ & 20 & 20 & 60 \\
\hline * Percentage by weight; Water to cement ratio (W:C): 0.5. Curing time-21 days (including 1 h carbonation curing).
\end{tabular}

\subsection{Carbonation Curing for $\mathrm{CO}_{2}$ Storage}

Capacity for $\mathrm{CO}_{2}$ storage of the product was investigated through a carbonation curing process during brick fabrication, which was conducted in a carbonation curing chamber with a size of $1.5 \mathrm{~m}$ in length and a diameter of $0.15 \mathrm{~m}$ (Figure 1). Prior to carbonation curing, the carbonation chamber was vacuumed to reduce the amount of free water and improve the absorption of $\mathrm{CO}_{2}$ in cube specimens. During the operation in the carbonation chamber, pure $\mathrm{CO}_{2}$ gas $(99.8 \%$ purity) was injected at an ambient pressure and continuously supplied throughout the carbonation period. The specimens were subjected to $\mathrm{CO}_{2}$ injection $24 \mathrm{~h}$ after demolding. At this phase, the bricks were perfectly shaped but were not completely hydrated such that $\mathrm{CO}_{2}$ could react with the mixture. The carbonation curing was set for 1,2 and $3 \mathrm{~h}$ to determine the effect of $\mathrm{CO}_{2}$ exposure time on the properties of the specimens. After the carbonation curing, brick specimens continued to undergo the curing process for 21 days. During the curing period, the relative humidity of the specimens was preserved to retain cement hydration. Uncarbonated brick specimens were used as the control in the estimation of the $\mathrm{CO}_{2}$ uptake of the bricks. The uncarbonated specimens contained the same proportion as the carbonated bricks but were not subjected to carbonation curing in the chamber. $\mathrm{CO}_{2}$ uptake during the carbonation curing was determined by the mass gain method, as shown in the following Equation [42].

$$
\mathrm{CO}_{2} \text { uptake }(\%)=\frac{M_{2}+M_{\text {water }}-M_{1}}{M_{\text {cement }}} \times 100 \%
$$

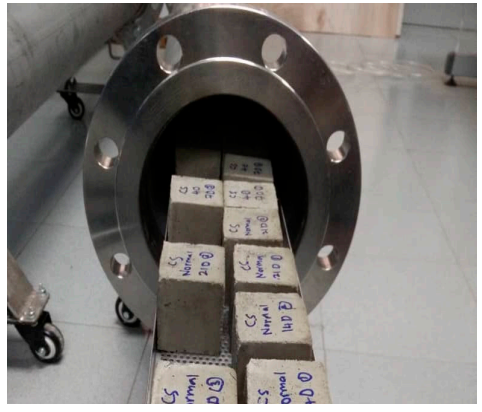

(a)

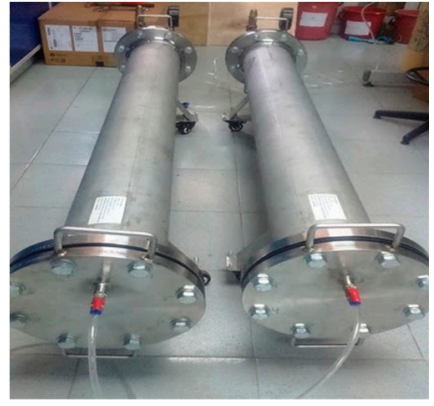

(b)

Figure 1. Carbonation curing process; (a) brick specimens undergo carbonation curing (b) carbonation chamber used in the experiment.

$M_{1}$ and $M_{2}$ represent the sample mass before and after the carbonation reaction, respectively. $M_{\text {water }}$ represents carbonation-induced water loss, while $M_{\text {cement }}$ represents the dry mass of cement. The change in the mass of the cube specimens was due to the absorption of $\mathrm{CO}_{2}$.

\section{Results}

\subsection{Mineralogical Characterization of Mine Waste}

A summary of the mineral composition of the mine waste samples is provided in Table 3 for waste rock, soil, sediment and sludge samples. It can be seen that gener- 
ally, the waste rock samples consisted mainly of quartz, $\mathrm{SiO}_{2}$ followed by muscovite, $\mathrm{K}(\mathrm{Mg}, \mathrm{Fe})_{3}\left(\mathrm{AlSi}_{3} \mathrm{O}_{10}\right)(\mathrm{OH})_{2}$; chlorite-serpentine, $(\mathrm{Mg}, \mathrm{Fe}, \mathrm{Al})_{6}(\mathrm{Si}, \mathrm{Al})_{4} \mathrm{O}_{10}(\mathrm{OH})_{8}$; graphite, C; kaolinite, $\mathrm{Al}_{2} \mathrm{Si}_{2} \mathrm{O}_{5}(\mathrm{OH})_{4}$; and albite, $\left(\mathrm{Na}_{0} \cdot{ }_{4} \mathrm{CaO}_{0 \cdot 16}\right) \mathrm{Al}_{1 \cdot 16} \mathrm{Si}_{2 \cdot 84} \mathrm{O}_{8}$ minerals. In waste rocks of the waste dump, quartz clearly dominated, with a moderate amount of chloriteserpentine and a minor amount of albite. In waste rocks of the stockpiles, quartz was majorly present with a moderate amount of muscovite and a minor amount of graphite. Kaolinite was present in a minor amount in the waste rocks of high-grade stockpile (HS). The XRD patterns of the waste rocks are portrayed in Figure 2, indicating the presence of these minerals.

Table 3. Summary of mineral composition of the waste rock, soil, sediment and sludge of gold mine waste.

\begin{tabular}{|c|c|c|c|c|c|c|}
\hline \multirow[b]{2}{*}{ Minerals } & \multicolumn{6}{|c|}{ Waste Rocks Samples } \\
\hline & WD & HS & SLS & LS & & \\
\hline Quartz, $\mathrm{SiO}_{2}$ & +++ & +++ & +++ & ++ & & \\
\hline Kaolinite, $\mathrm{Al}_{2} \mathrm{Si}_{2} \mathrm{O}_{5}(\mathrm{OH})_{4}$ & - & + & - & - & & \\
\hline Chlorite-serpentine, $(\mathrm{Mg}, \mathrm{Al})_{6}(\mathrm{Si}, \mathrm{Al})_{4} \mathrm{O}_{10}(\mathrm{OH})_{8}$ & ++ & - & - & - & & \\
\hline Muscovite, $\mathrm{K}(\mathrm{Mg}, \mathrm{Fe})_{3}\left(\mathrm{AlSi}_{3} \mathrm{O}_{10}\right)(\mathrm{OH})_{2}$ & - & ++ & ++ & ++ & & \\
\hline Albite, $\left(\mathrm{Na}_{0} \cdot 84 \mathrm{CaO}_{0 \cdot 16}\right) \mathrm{Al}_{1 \cdot 16} \mathrm{Si}_{2 \cdot 84} \mathrm{O}_{8}$ & + & - & - & - & & \\
\hline \multirow[t]{2}{*}{ Graphite, C } & - & + & + & + & & \\
\hline & \multicolumn{6}{|c|}{ Soil, sediment and sludge samples } \\
\hline Minerals & WD & HS & SLS & LS & SED & SLU \\
\hline Quartz, $\mathrm{SiO}_{2}$ & - & - & - & - & ++ & ++ \\
\hline Kaolinite, $\mathrm{Al}_{2} \mathrm{Si}_{2} \mathrm{O}_{5}(\mathrm{OH})_{4}$ & +++ & +++ & +++ & - & - & - \\
\hline Illite, $\left(\mathrm{K}, \mathrm{H}_{3} \mathrm{O}\right)(\mathrm{Al}, \mathrm{Mg}, \mathrm{Fe})_{2}(\mathrm{Si}, \mathrm{Al})_{4} \mathrm{O}_{10}\left[(\mathrm{OH})_{2},\left(\mathrm{H}_{2} \mathrm{O}\right)\right]$ & +++ & +++ & +++ & +++ & +++ & +++ \\
\hline Chlorite-serpentine, $(\mathrm{Mg}, \mathrm{Al})_{6}(\mathrm{Si}, \mathrm{Al})_{4} \mathrm{O}_{10}(\mathrm{OH})_{8}$ & - & - & - & - & ++ & ++ \\
\hline Aerinite, $\left[\left(\mathrm{Fe}^{+2}, \mathrm{Fe}^{+3}, \mathrm{Al}\right)_{3} \mathrm{Mg}_{3}(\mathrm{Ca}, \mathrm{Na})_{4}\left(\mathrm{Si}_{13.5} \mathrm{Al}_{4 \cdot 5} \mathrm{O}_{42}\right)(\mathrm{OH})_{6}\right] \cdot 12 \mathrm{H}_{2} \mathrm{O}$ & ++ & - & - & - & - & - \\
\hline Polythionite, $\mathrm{K}(\mathrm{AlFeLi})\left(\mathrm{Si}_{3} \mathrm{Al}\right) \mathrm{O}_{10}(\mathrm{OH}) \mathrm{F}$ & - & - & + & - & - & - \\
\hline Stilpnomelane, $\mathrm{Fe}_{2} \mathrm{Si}_{3} \mathrm{O}_{9}$ & - & - & - & + & - & - \\
\hline
\end{tabular}

+++ Major (>30\%); ++ Moderate (10-30\%); + Minor (2-10\%); - trace $(<2 \%)$ mineral phases (identified from percentage of relative weight from XRD analysis).

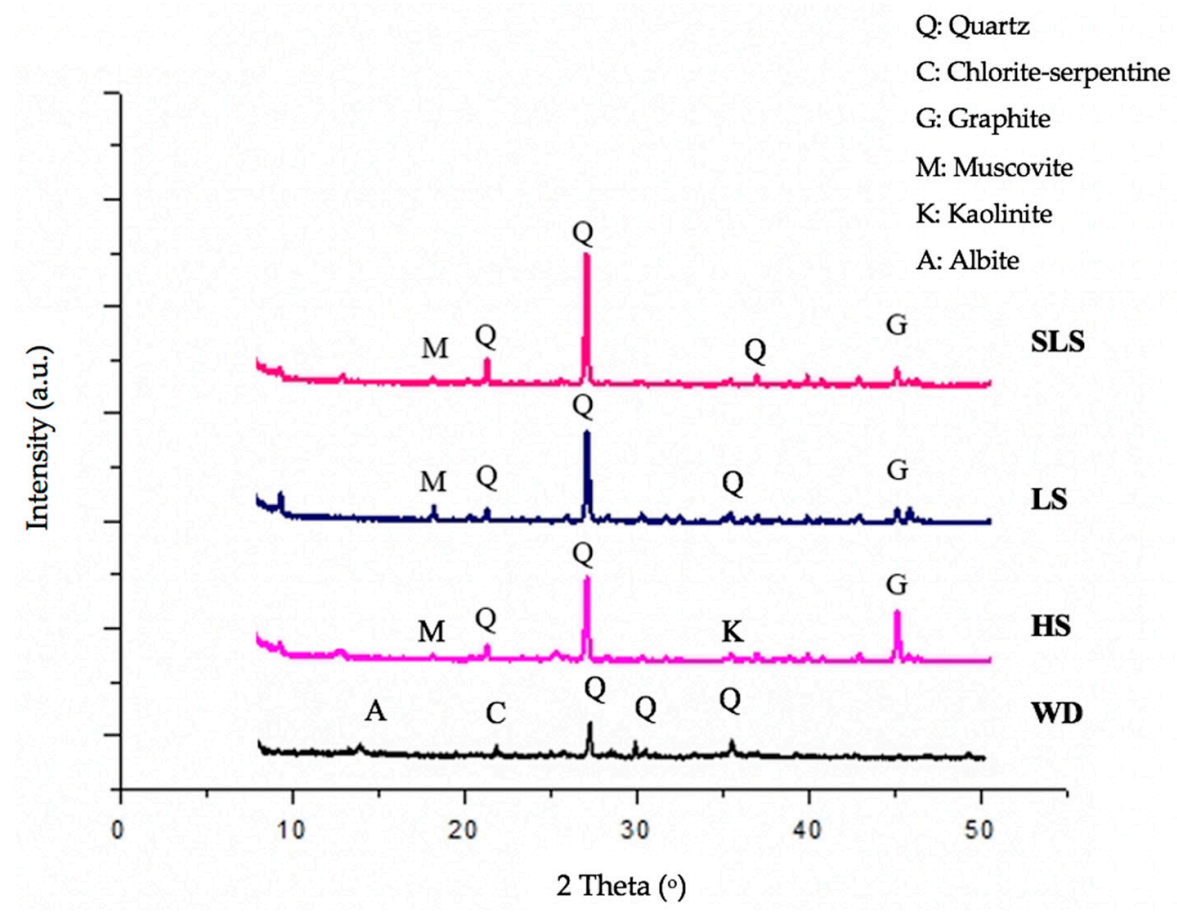

Figure 2. X-ray diffractograms of waste rocks in waste dump and stockpiles.

On the other hand, the soil samples (of waste dump and stockpiles) consisted mainly of illite, $\left(\mathrm{K}, \mathrm{H}_{3} \mathrm{O}\right)(\mathrm{Al}, \mathrm{Mg}, \mathrm{Fe})_{2}(\mathrm{Si}, \mathrm{Al})_{4} \mathrm{O}_{10}\left[(\mathrm{OH})_{2},\left(\mathrm{H}_{2} \mathrm{O}\right)\right.$ and kaolinite, with a moderate amount 
of aerinite, $\left.\left(\left(\mathrm{Fe}^{+2}, \mathrm{Fe}^{+3}, \mathrm{Al}\right) 3 \mathrm{Mg}_{3}(\mathrm{Ca}, \mathrm{Na})_{4}\left(\mathrm{Si}_{13 \cdot 5} \mathrm{Al}_{4 \cdot 5} \mathrm{O}_{42}\right)(\mathrm{OH})_{6}\right] \cdot{ }_{11 \cdot 3} \mathrm{H}_{2} \mathrm{O}\right)$, and a minor amount of stilpnomelane, $\mathrm{Fe}_{2}\left(\mathrm{Si}_{3} \mathrm{O}_{9}\right)$ and polylithionite, $\mathrm{K}(\mathrm{AlFeLi})\left(\mathrm{Si}_{3} \mathrm{Al}\right) \mathrm{O}_{10}(\mathrm{OH}) \mathrm{F}$ minerals. Specifically, kaolinite and illite were present in all the soil samples. Aerinite was only present in the soil sample of the waste dump, while polylithionite was only present in the stockpile (SLS) and stilpnomelane was only found in the stockpile (LS) sample. The sediment and sludge were composed of the same types of minerals, where illite was the major mineral, followed by chlorite-serpentine and quartz. The XRD patterns of the soil samples are illustrated in Figure $3 \mathrm{a}$, and the sludge and sediment samples are demonstrated in Figure $3 b$. The presence of the same minerals in the different samples indicated that they were originally derived from the same set of host rock and ore [54].

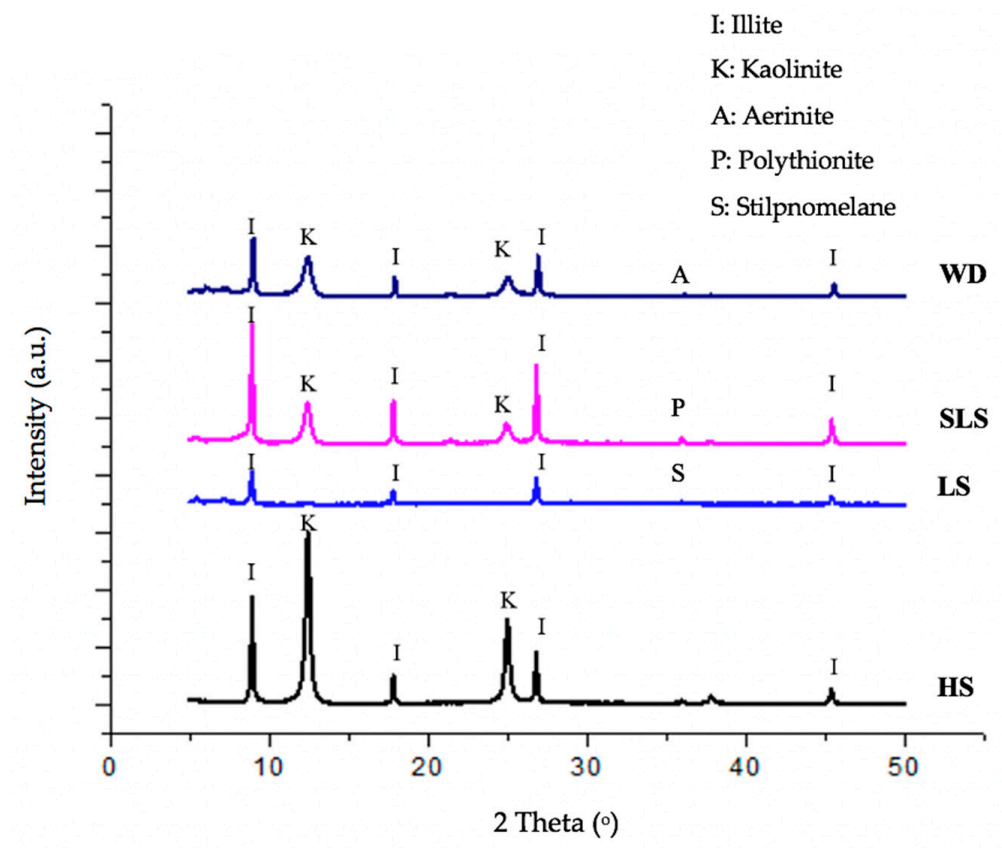

(a)

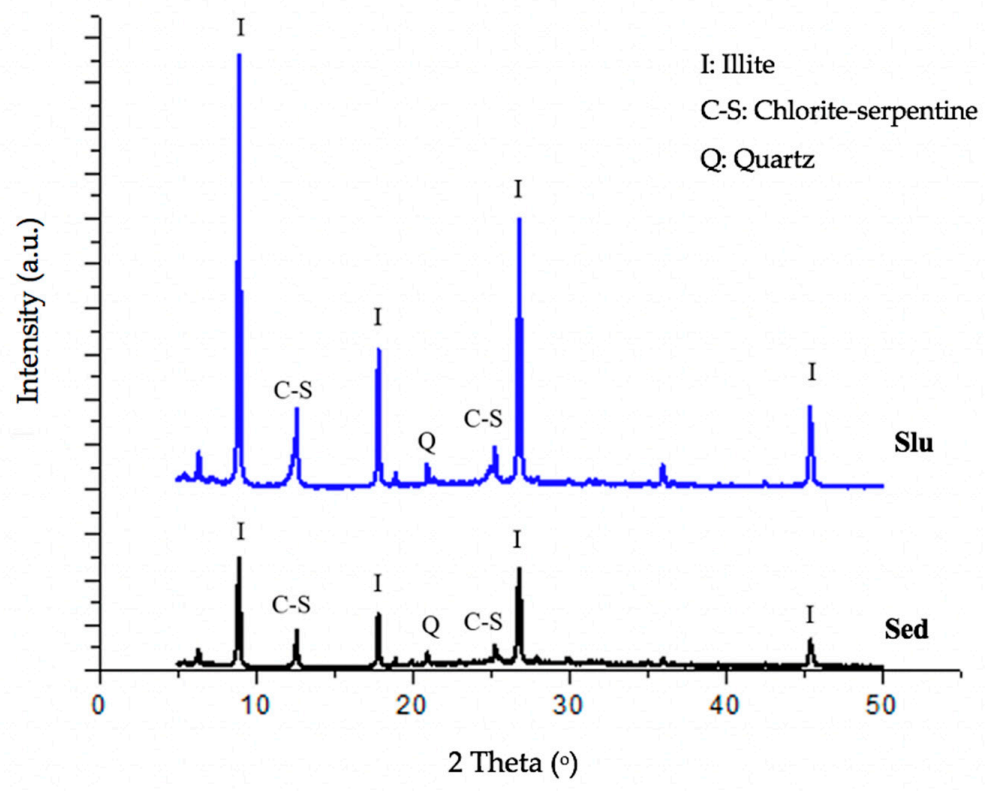

(b)

Figure 3. X-ray diffractograms of (a) soils in waste dump and stockpiles (b) sediment and sludge of mine tailings. 
Overall, the waste rock samples were dominated by muscovite alongside the quartz. The soil was dominated by illite and kaolinite, while sediment and sludge were dominated by illite alongside the quartz. Clearly, the mine waste was composed of various $\mathrm{Mg}-\mathrm{Fe}$ silicate minerals that are potentially useful for mineral carbonation [55]. These silicate minerals are mostly phyllosilicate. Among the phyllosilicate groups, illite and kaolinite are classified as clay minerals, muscovite is known as mica, and chlorite-serpentine are under chlorite and serpentine subgroups. These minerals are also regarded as aluminosilicates (minerals composed of aluminum, silicon and oxygen), which is a major component in clay minerals. Clay minerals are typically formed as the product of chemical weathering of silicate minerals at the earth's surface. More importantly, the presence of clay minerals can be associated with $\mathrm{CO}_{2}$ adsorption, thus suggesting its potential for $\mathrm{CO}_{2}$ capture most likely by means of mineral carbonation [56,57]. The importance of mine waste rock for carbon capture has been highlighted in Hitch et al. [17], and its utilization in concrete-based materials has been discussed in Steinour [58] among the earliest reported in the literature.

\subsection{Physicochemical Composition of Mine Waste}

Table 4 shows the results of the particle size distribution of the soil, sediment and sludge samples to determine the amount of silt and clay in the mine waste. The waste rock samples were not subjected to particle size distribution as samples are mostly sandy. The analysis classifies the soil, sediment and sludge samples as containing greater proportion of fines (clay and silt) (Figure 4). Fineness is a very important characteristic of a material to be used as partial replacement for cement, i.e., fine particles of greater than $30 \%$ [59]. The soil textural classes were based on the United State Department of Agriculture (USDA) soil textural triangle. The particle size distribution of the mine waste samples was in the range of $6.96-19.17 \%$ (clay), $38.08-78.23 \%$ (silt) and $4.28-42.77 \%$ (sand) fractions. Results indicated that the particle size of the gold mine wastes suggested mostly silt loam. The highest silt content was found in tailing sludge (78.23\%), followed by waste dump (68.06\%), stockpile HS (63.98\%), stockpile SLS (60.65\%), tailing sediment (53.21\%) and stockpile LS $(38.08 \%)$. Therefore, the mine waste samples have satisfied the requirement for use as supplementary cementitious material in terms of their particle size having greater than $30 \%$ of total fine particles, i.e., between 57.25 and $95.66 \%$.

Table 4. Particle size classification of gold mine waste samples.

\begin{tabular}{|c|c|c|c|c|c|c|c|}
\hline & & WD & HS & LS & SLS & SLU & SED \\
\hline Clay & $<2 \mu \mathrm{m}$ & 11.16 & 10.8 & 19.17 & 7.25 & 17.43 & 6.96 \\
\hline Silt & $2-50 \mu \mathrm{m}$ & 68.06 & 63.98 & 38.08 & 60.65 & 78.23 & 53.21 \\
\hline Sand & $>50 \mu \mathrm{m}$ & 20.66 & 25.17 & 42.77 & 32.01 & 4.28 & 39.74 \\
\hline \multicolumn{2}{|c|}{$\begin{array}{l}\text { Total fines } \\
\text { (clay }+ \text { silt })\end{array}$} & 79.22 & 74.78 & 57.25 & 67.9 & 95.66 & 60.17 \\
\hline \multicolumn{2}{|c|}{ Soil texture class (USDA) } & Silt loam & Silt loam & Silt loam & Silt loam & Silt loam & Silt loam \\
\hline
\end{tabular}

The chemical composition of the mine waste samples are shown in Table 5, which are given as the percentages of major oxide elements including $\mathrm{MgO}, \mathrm{Fe}_{2} \mathrm{O}_{3}, \mathrm{Al}_{2} \mathrm{O}_{3}, \mathrm{~K}_{2} \mathrm{O}, \mathrm{SO}_{3}$, $\mathrm{SiO}_{2}$ and $\mathrm{Na}_{2} \mathrm{O}$. It is noticeable that $\mathrm{SiO}_{2}$ was dominating in all samples with the percentage ranging between 48.46 and $71.06 \%$. It is followed by $\mathrm{Al}_{2} \mathrm{O}_{3}$, which ranges between 19.22 and $29.93 \%$. Both $\mathrm{SiO}_{2}$ and $\mathrm{Al}_{2} \mathrm{O}_{3}$ were detected at relatively higher amounts compared to other oxide elements in all samples, confirming that the mine waste samples were of aluminosilicate material. Alumina-silicate is an important mineral composition that can be incorporated as supplementary cementitious material and is an essential element in cement- or concrete-based materials [47,60]. On the other hand, $\mathrm{MgO}$ was found in the waste rock sample of the waste dump, soil sample of the stockpile (HS and LS) and in the sludge, ranging between 1.74 and $5.74 \% . \mathrm{Fe}_{2} \mathrm{O}_{3}$ were found in all the soil, sediment and sludge samples and the waste rocks of the waste dump, ranging between 3.04 and 11.79\%. 


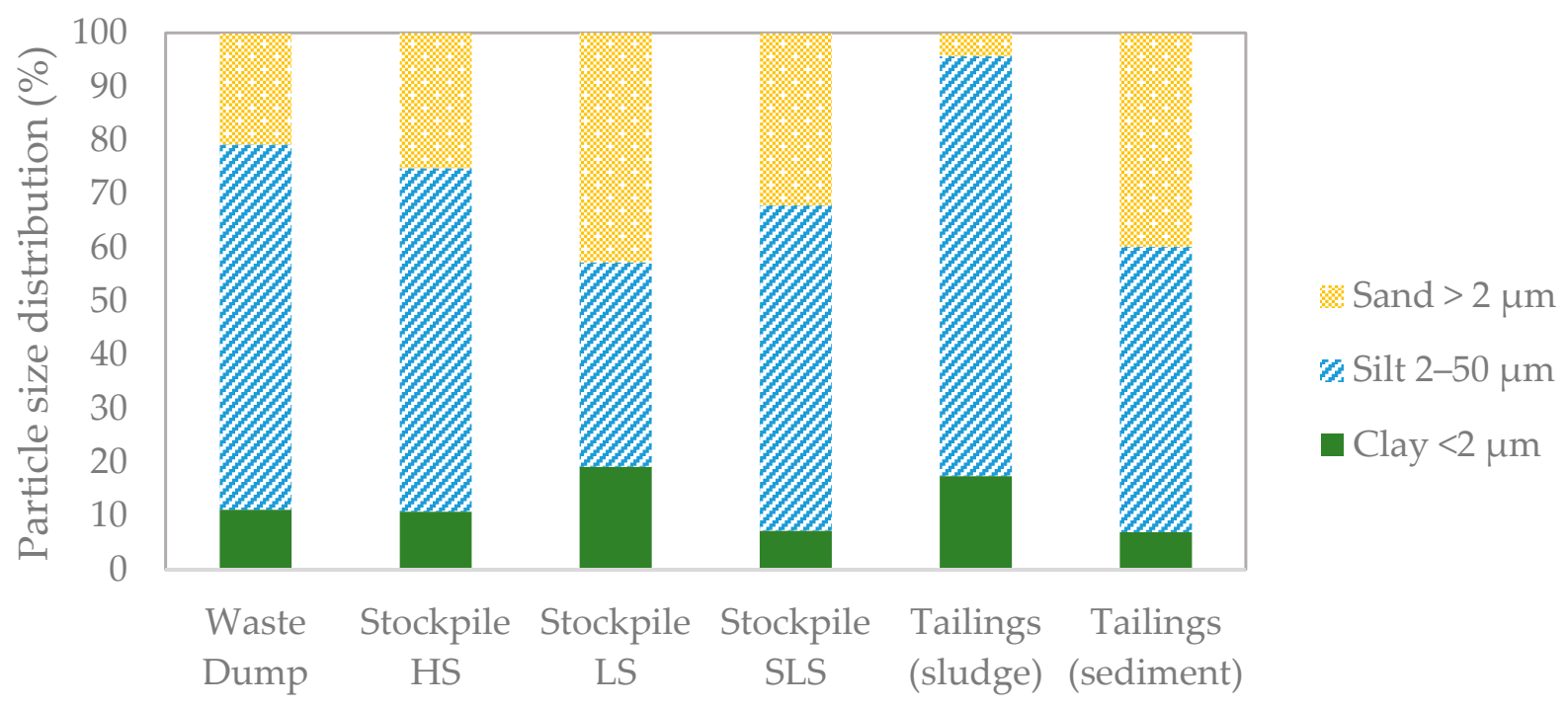

Figure 4. Particle size distribution of gold mine waste samples.

Table 5. Chemical composition given as (wt.\%) of major oxides of gold mine waste samples.

\begin{tabular}{|c|c|c|c|c|c|c|}
\hline \multirow[b]{3}{*}{ Chemical Composition } & \multicolumn{6}{|c|}{ Percent Composition (wt.\%) } \\
\hline & \multicolumn{6}{|c|}{ Waste Rocks Samples } \\
\hline & WD & HS & SLS & LS & & \\
\hline${ }^{+} \mathrm{Fe}_{2} \mathrm{O}_{3}$ & 5.71 & - & - & - & & \\
\hline${ }^{+} \mathrm{MgO}$ & 5.74 & - & - & - & & \\
\hline $\mathrm{SiO}_{2}$ & 57.81 & 70.17 & 71.06 & 64.35 & & \\
\hline $\mathrm{SO}_{3}$ & & 0.47 & 4.85 & 3.31 & & \\
\hline $\mathrm{Al}_{2} \mathrm{O}_{3}$ & 24.35 & 24.17 & 20.55 & 22.62 & & \\
\hline $\mathrm{K}_{2} \mathrm{O}$ & 4.94 & 5.01 & 2.60 & 8.91 & & \\
\hline $\mathrm{Na}_{2} \mathrm{O}$ & 0.53 & - & 0.68 & - & & \\
\hline \multirow[t]{3}{*}{ Pozzolanic oxides ${ }^{++}$} & 87.87 & 94.34 & 91.61 & 84.97 & & \\
\hline & \multicolumn{6}{|c|}{ Percent composition (wt.\%) } \\
\hline & \multicolumn{6}{|c|}{ Soil, sediment and sludge samples } \\
\hline Chemical composition & WD & HS & SLS & LS & SED & SLU \\
\hline$+{ }^{+} \mathrm{Fe}_{2} \mathrm{O}_{3}$ & 3.60 & 2.91 & 3.15 & 11.79 & 3.04 & 3.20 \\
\hline$+\mathrm{MgO}$ & - & 2.13 & - & 2.72 & - & 1.74 \\
\hline $\mathrm{SiO}_{2}$ & 59.53 & 64.61 & 67.9 & 48.46 & 64.7 & 63.39 \\
\hline $\mathrm{SO}_{3}$ & - & 2.53 & - & 8.83 & 4.32 & 4.37 \\
\hline $\mathrm{Al}_{2} \mathrm{O}_{3}$ & 29.93 & 24.84 & 22.82 & 20.18 & 19.6 & 19.22 \\
\hline $\mathrm{K}_{2} \mathrm{O}$ & 6.36 & 3.00 & 5.72 & 7.24 & 6.63 & 7.06 \\
\hline $\mathrm{Na}_{2} \mathrm{O}$ & 0.48 & 0.1 & 0.31 & 0.68 & 0.48 & 0.45 \\
\hline Pozzolanic oxides ${ }^{++}$ & 93.06 & 94.36 & 93.87 & 80.43 & 87.34 & 84.81 \\
\hline
\end{tabular}

${ }^{+}$Important oxide minerals for mineral carbonation. ${ }^{++}$Pozzolanic oxides (Sum of $\mathrm{SiO}_{2}+\mathrm{Al}_{2} \mathrm{O}_{3}+\mathrm{Fe}_{2} \mathrm{O}_{3}$ ).

Clearly, the presence of $\mathrm{MgO}$ and $\mathrm{Fe}_{2} \mathrm{O}_{3}$ in the samples can be associated with minerals muscovite $\mathrm{K}(\mathrm{Mg}, \mathrm{Fe})_{3}\left(\mathrm{AlSi}_{3} \mathrm{O}_{10}\right)(\mathrm{OH})_{2}$, illite $\left(\mathrm{K}_{,} \mathrm{H}_{3} \mathrm{O}\right)(\mathrm{Al}, \mathrm{Mg}, \mathrm{Fe})_{2}(\mathrm{Si}, \mathrm{Al})_{4} \mathrm{O}_{10}\left[(\mathrm{OH})_{2},\left(\mathrm{H}_{2} \mathrm{O}\right)\right]$ and aerinite $\left[\left(\mathrm{Fe}^{+2}, \mathrm{Fe}^{+3}, \mathrm{Al}_{3} \mathrm{Mg}_{3}(\mathrm{Ca}, \mathrm{Na})_{4}\left(\mathrm{Si}_{13} \cdot 5 \mathrm{Al}_{4 \cdot 5} \mathrm{O}_{42}\right)(\mathrm{OH})_{6}\right] \cdot 12 \mathrm{H}_{2} \mathrm{O}\right.$, as noted earlier, while $\mathrm{Al}_{2} \mathrm{O}_{3}$ is attributable to minerals kaolinite $\mathrm{Al}_{2} \mathrm{Si}_{2} \mathrm{O}_{5}(\mathrm{OH})_{4}$, chlorite-serpentine $(\mathrm{Mg}, \mathrm{Al})_{6}(\mathrm{Si}, \mathrm{Al})_{4} \mathrm{O}_{10}(\mathrm{OH})_{8}$, muscovite, illite and aerinite. This shows that the mine wastes have a considerable amount of silicate minerals, which contain important oxide minerals known to be essential for mineral carbonation. In particular, the presence of $\mathrm{Mg}$ - and Fe-bearing silicates in the samples are ideal for mineral carbonation, the process that captures $\mathrm{CO}_{2}$. It was noticeable that $\mathrm{MgO}$ is present in some samples of the gold mine waste. The importance of $\mathrm{Mg}$-silicates for carbonation in a cementitious product has been highlighted in Mo et al. [44]. Additionally, $\mathrm{Fe}_{2} \mathrm{O}_{3}$ is noticeable in most samples, which is another important oxide mineral that can influence mineral carbonation. However, the 
contribution of Mg- and Ca-silicates/oxides for mineral carbonation has been known to be more influential than other silicate/oxide minerals [29]. The process of mineral carbonation can naturally occur in the presence of metal oxide-bearing minerals such as magnesium, calcium and iron oxides, which are converted into carbonate minerals and elemental silica upon reaction with $\mathrm{CO}_{2}$ [19]. These minerals are likely suitable for carbon sequestration as the product is geologically stable and thus can potentially capture $\mathrm{CO}_{2}$ emission over time [61].

As can be seen in Table 5, the mine waste samples are highly pozzolanic, as they contain pozzolanic oxides of $\mathrm{SiO}_{2}, \mathrm{Al}_{2} \mathrm{O}_{3}$ and $\mathrm{Fe}_{2} \mathrm{O}_{3}$, i.e., greater than $70 \%$. Pozzolans are materials with an amorphous siliceous or siliceous and aluminous content that react with calcium hydroxide, $\mathrm{Ca}(\mathrm{OH})_{2}$ (lime), in the presence of water to form cementitious hydration products, e.g., calcium silicate hydrates and calcium silicate aluminate hydrates [62]. Pozzolans have been used to improve the properties of lime and most commonly the ordinary Portland cement in building structures. Furthermore, it has been studied that pozzolan properties such as particle size, specific surface, chemical and mineral composition, amorphousness and water demand affect the reactivity and strength of cementitious materials [62]. Therefore, the chemical and mineral properties of the mine waste samples are of great importance that could influence the pozzolanic behavior as well as the potential for carbon sequestration.

Figure 5 shows the SEM images of the mine waste samples at $\times 3.00 \mathrm{k}$ magnification. SEM images support the XRD results that quartz and muscovite were dominating in waste rocks. Quartz can be seen as euhedral crystals and indented contacts between detrital grains of quartz in Figure 5a-d. Detrital muscovite is present as flexed mica crystals in Figure 5c,d, while it has been known that muscovite mica can be attributed to an overlapping set of parallel plates, a lamellar structure [63]. Some alteration of muscovite to kaolinite can be possible as seen in previous studies of clay minerals [63,64]. Both illite and kaolinite were mostly distributed in the soil, sludge and sediment of gold mining waste. As shown in Figure $5 g-i$, there are pseudohexagonal shapes of crystals that are often identified as kaolinite, i.e., cluster or blocky kaolinite of 5-10 $\mu \mathrm{m}$ in thickness [64], although other largerstructured minerals may have the same shape [65]. The appearance of a sheet-like to curled form and a flaky form with a scale-like morphology is identified as illite (Figure 5e-j) [66]. Chloride-serpentine formations that are present as shown in Figure 5a,i,j are indicated by the tabular shape of crystals as relatively coarse detrital grains in the figures [66].

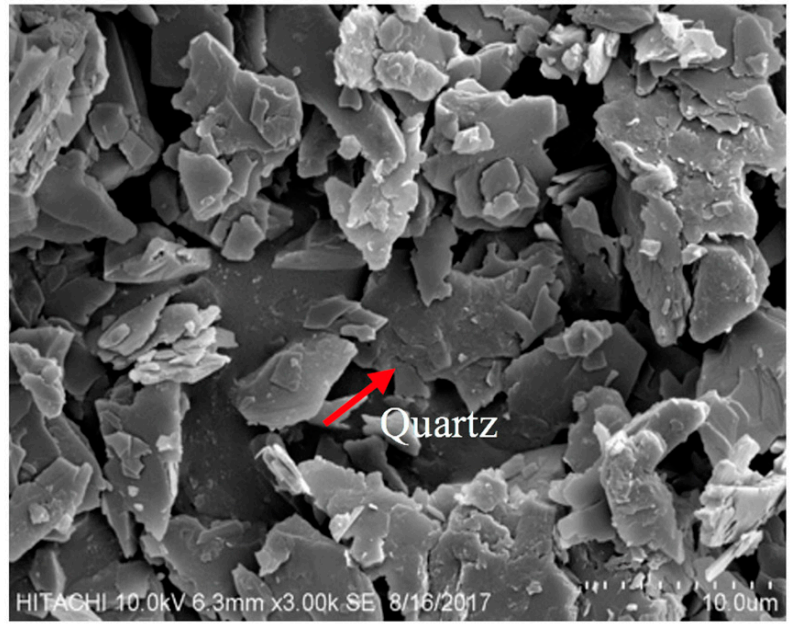

(a)

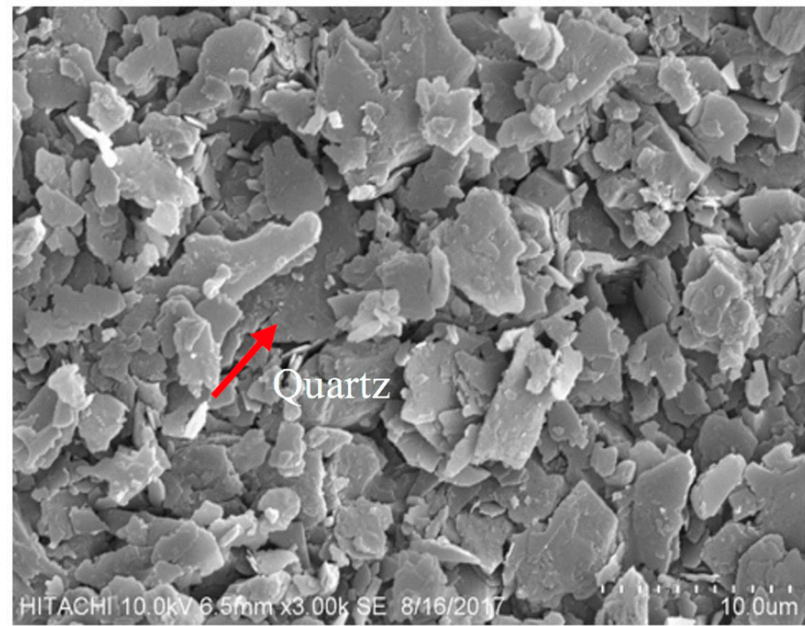

(b)

Figure 5. Cont. 


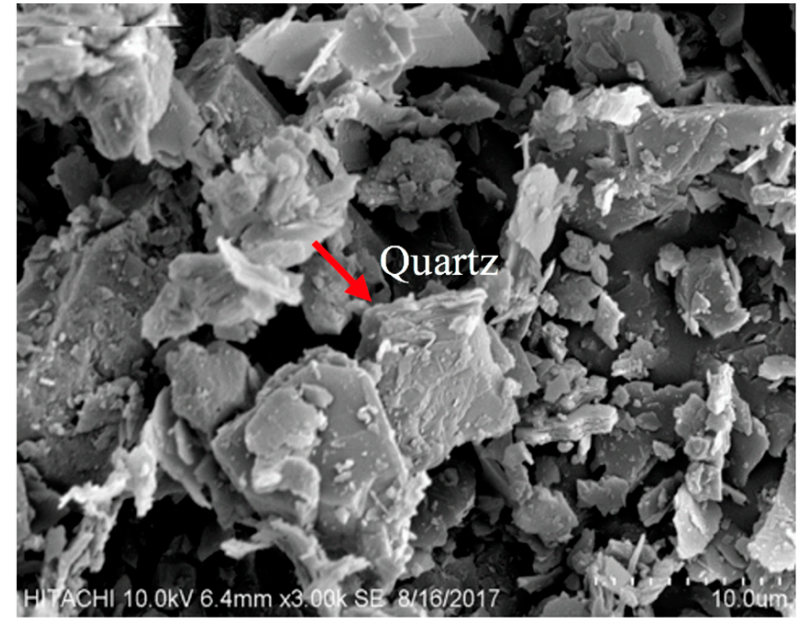

(c)

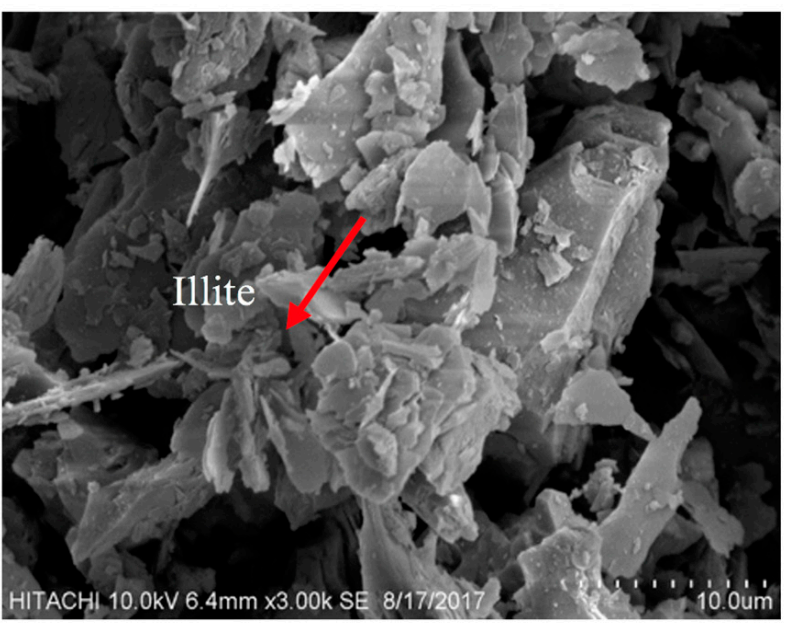

(e)

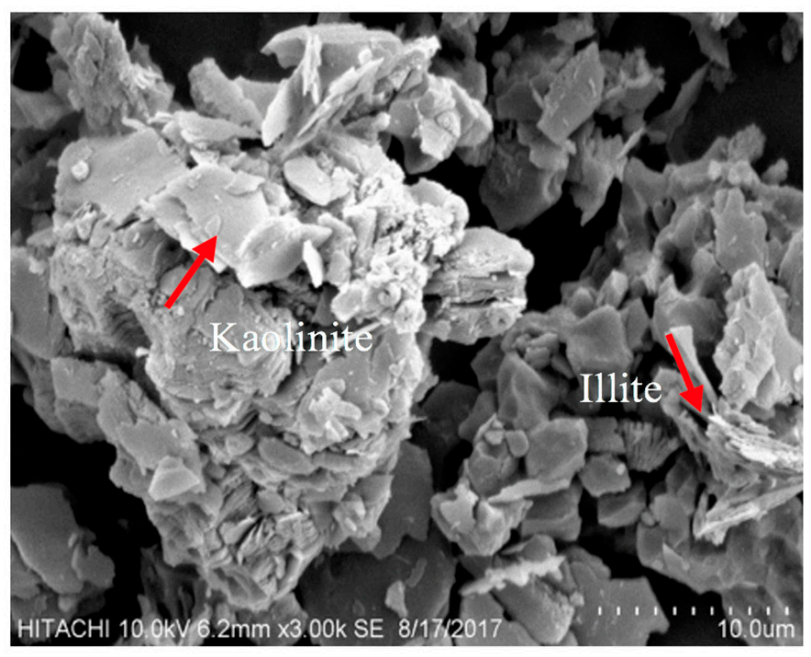

(g)

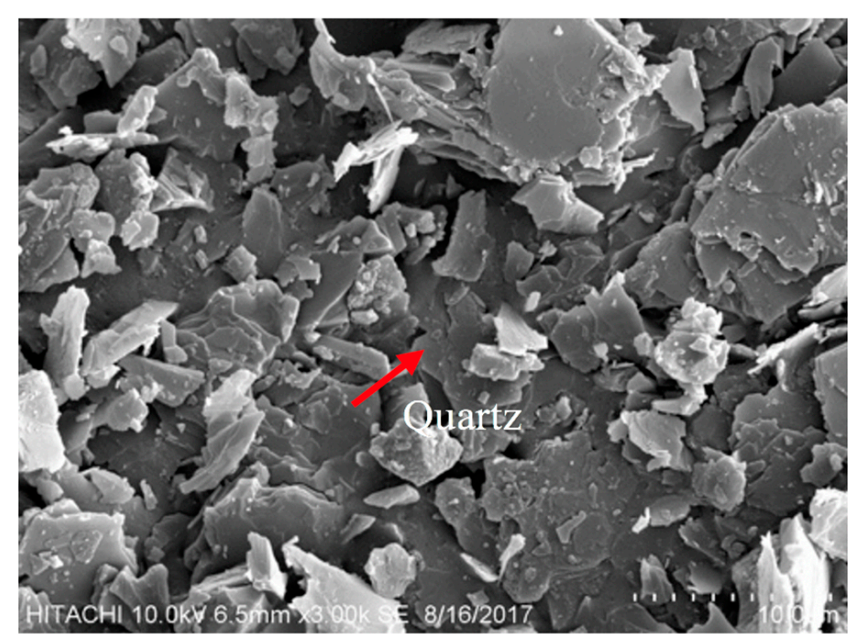

(d)

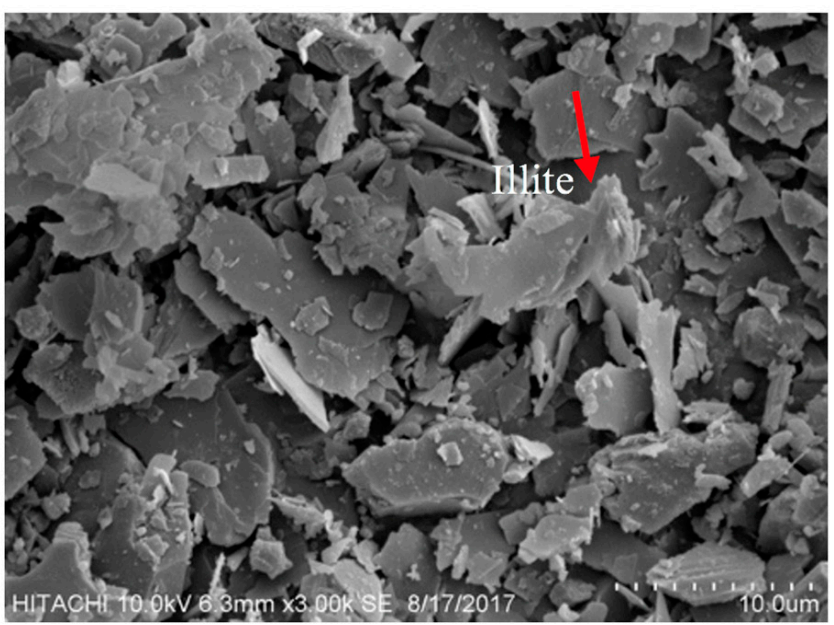

(f)

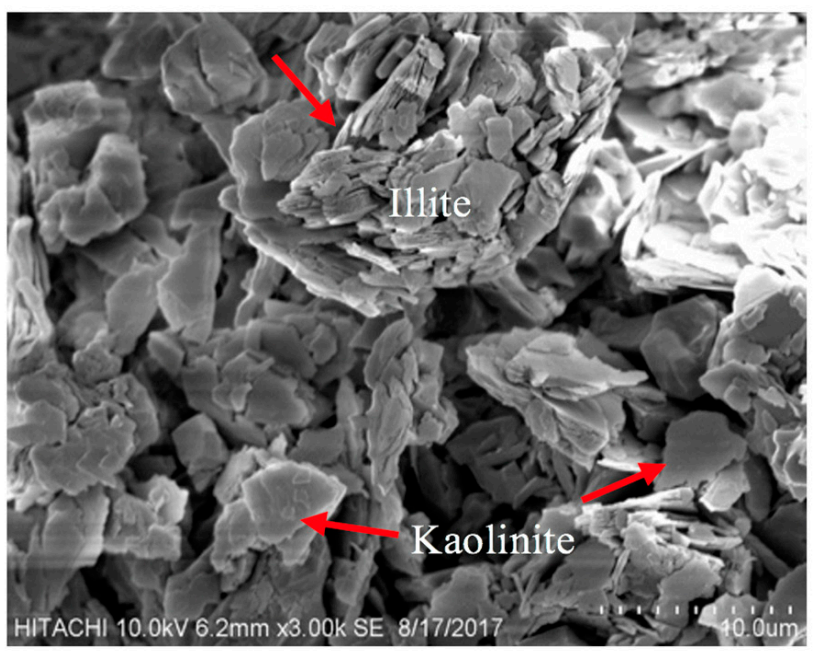

(h)

Figure 5. Cont. 


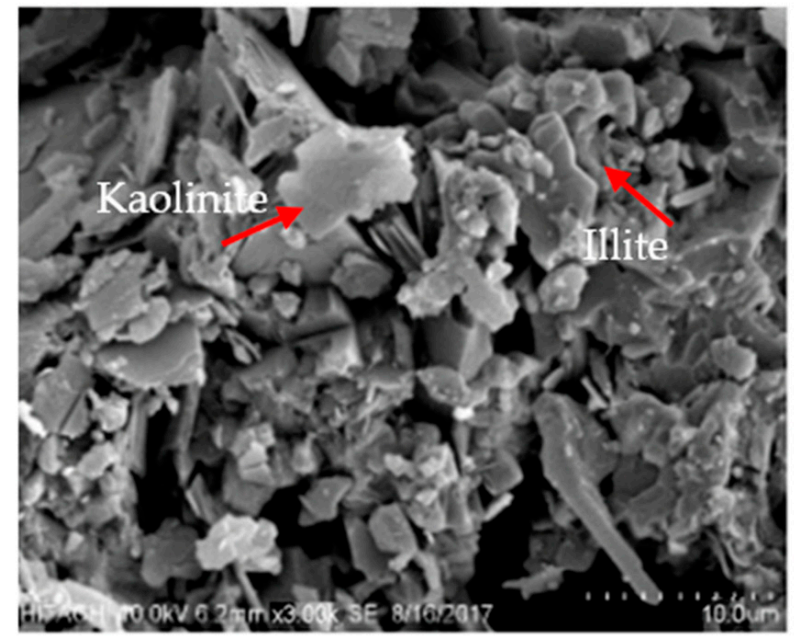

(i)

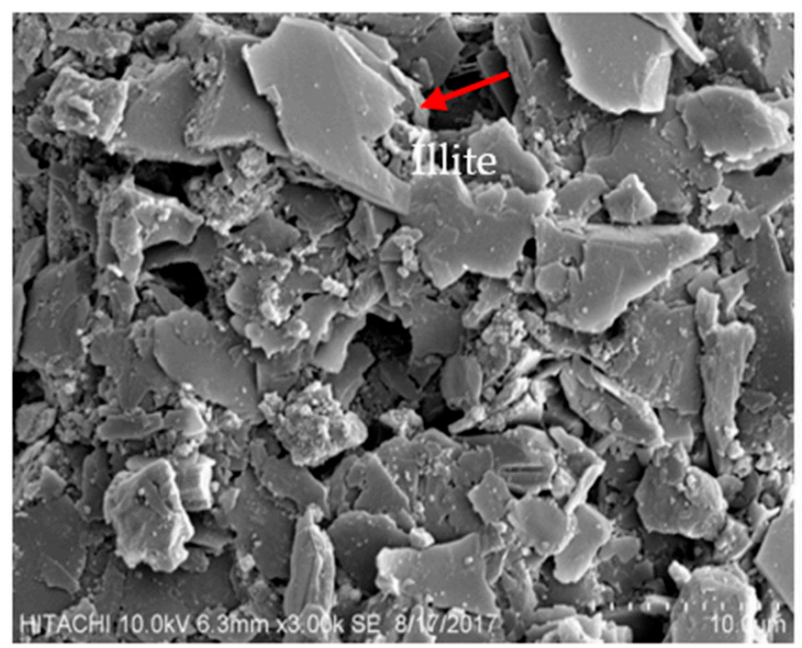

$(\mathbf{j})$

Figure 5. Scanning electron micrographs (SEM) images for different samples. Rock samples: waste dump (a), high-grade stockpile (b), super-low-grade stockpile (c), low-grade stockpile (d). Sediment sample (e), sludge sample (f), soil samples waste dump (g), high-grade stockpile (h), super-low-grade stockpile (i), and low-grade stockpile (j) at $\times 3.00 \mathrm{k}$ magnification.

\subsection{Mine Waste Utilization as Supplementary Cementitious Material for Carbon Capture}

An important aspect of the sequestering potential is carbon storage and its utilization. From the point of view of CCUS, the use of mine waste can be regarded as a beneficial feedstock for mineral carbonation and can serve as a supplementary cementitious material in the production of cement-based products. In this study, a cement-based product (brick) was developed using the mine waste while assessing its potential in capturing $\mathrm{CO}_{2}$ during the production phase. The proportion of mine waste was varied from $40 \%$ to $60 \%$ as partial replacement for ordinary Portland cement, thereby reducing the use of manufactured cement often associated with waste-oriented material. This is mainly due to the composition of minerals of the mine waste that is pozzolanic, which can help improve the strength properties of the material. From a carbon sequestration perspective, the carbonation reaction of components such as $\mathrm{CaO}$ and $\mathrm{MgO}$ will produce carbonate minerals that can act as additional binders, which can increase the strength of cement-based materials. Similarly, aluminosilicate minerals are preferable as a supplementary cementitious material in the production of cement-based materials.

The criteria of the brick material fabricated using the mine waste are as presented in Table 6. Notably, all the bricks made of the gold mine waste have surpassed the standard specifications for load-bearing bricks according to Malaysian Standards, MS 1933-1: 2007 [67]. The compressive strength of the bricks was in the range of $19.5-29.5 \mathrm{~N} / \mathrm{mm}^{2}$, which is classified as classes $2-4$ of load-bearing brick. The water absorption ranged between 1.4 and $2.2 \%$, which is below the $7.0 \%$ level of maximum absorption. Therefore, incorporation of mine waste has met the standard criteria and has been useful in reducing the use of commercial ordinary Portland cement while securing its potential for carbon capture.

The availability of storage capacity of mine waste gives it potential for carbon to be sequestered. This was evaluated through the sequestering potential of the mine waste brick as given by the amount of $\mathrm{CO}_{2}$ that can be captured through its production phase. Mineral carbonation was incorporated through the process of carbonation curing during brick fabrication. The bricks were exposed to a carbonation curing period of 1 to estimate the amount of $\mathrm{CO}_{2}$ captured. Table 7 demonstrates the sequestered amount of $\mathrm{CO}_{2}$ of the carbonated brick product. It can be seen that the $\mathrm{CO}_{2}$ uptake is between 0.24 and $0.57 \%$ for the bricks containing 40 to $60 \%$ of gold mine waste. Note that $\mathrm{CO}_{2}$ uptake was also detectable for the control brick (not containing mine waste), suggesting that cementitious 
compound may also capture $\mathrm{CO}_{2}$. The resulting amount of sequestered $\mathrm{CO}_{2}$ of the mine waste bricks was estimated to be between 7.2 and $17.1 \mathrm{~g} \mathrm{CO}_{2} /$ brick product.

Table 6. Criteria of the cement-based product (bricks) and sequestered $\mathrm{CO}_{2}$ in carbonated brick product at $1 \mathrm{~h}$ carbonation.

\begin{tabular}{|c|c|c|c|c|}
\hline Brick Type & $\begin{array}{l}\text { Compressive Strength } \\
\text { (N/mm2) }\end{array}$ & Water Absorption (\%) & CO2 Uptake (\%) & $\begin{array}{l}\text { Sequestered CO2 } \\
\text { (g CO2/brick) }\end{array}$ \\
\hline NB & 24.1 & 1.4 & 0.17 & 5.1 \\
\hline GMW40 & 19.5 & 1.7 & 0.30 & 9.0 \\
\hline GMW50 & 23.3 & 1.4 & 0.24 & 7.2 \\
\hline GMW60 & 29.5 & 2.2 & 0.57 & 17.1 \\
\hline Load bearing brick & $7-103.5 \mathrm{~N} / \mathrm{mm}^{2}$ & $\begin{array}{l}\text { Standard specifications } \\
\text { No specific } \\
\text { requirements }\end{array}$ & & \\
\hline Engineering brick & $48.5-69 \mathrm{~N} / \mathrm{mm}^{2}$ & $4.5-7.0 \%$ & & \\
\hline
\end{tabular}

Table 7. Chemical compound (\%) after carbonation.

\begin{tabular}{cccc}
\hline Chemical Composition & Uncarbonated & $\mathbf{1} \mathbf{h}$ & $\mathbf{3} \mathbf{h}$ \\
\hline $\mathrm{CaO}$ & 32.2 & 41.2 & 46.7 \\
$\mathrm{Fe}_{2} \mathrm{O}_{3}$ & 3.6 & 3.9 & 5.4 \\
$\mathrm{MgO}$ & 1.3 & 1.9 & 2.8 \\
$\mathrm{SiO}_{2}$ & 43.7 & 36.2 & 29.6 \\
$\mathrm{SO}_{3}$ & 1.5 & 0.9 & 1.1 \\
$\mathrm{Al}_{2} \mathrm{O}_{3}$ & 14.7 & 12.5 & 12.3 \\
$\mathrm{~K}_{2} \mathrm{O}$ & 3.5 & 2.8 & 2.7 \\
$\mathrm{Na}_{2} \mathrm{O}$ & 0.4 & 0.4 & 0.3 \\
\hline
\end{tabular}

Chemical compound of GMW50.

\subsection{Carbon Capture and Storage in Cementitious Product}

The effect of carbonation on brick performance was further evaluated using brick specimens exposed to 1, 2 and $3 \mathrm{~h}$ of carbonation (Figure 6). It can be seen that as carbonation time increases to $3 \mathrm{~h}$, compressive strength notably increased, while water adsorption greatly decreased. It is noticeable that at $3 \mathrm{~h}$ carbonation, brick performances (compressive strength and water absorption) markedly improved compared to $1 \mathrm{~h}$ and $2 \mathrm{~h}$ carbonation time (differences are significant at $p<0.01$ ). For each ratio of mine waste in the bricks, greater performance was clearly observed for carbonated bricks compared to uncarbonated ones, suggesting that carbonation may help improve brick properties. Generally, it is known that the strength of cement-based material is derived from its formation of calcium silicate hydrate (C-S-H) when hydrated. In carbonated bricks, improvement in strength can be associated with the formation of carbonated particles such as $\mathrm{Ca}$ and/or $\mathrm{Mg}$ carbonates which are the micro-sized particles that can fill the pores in cementitious material that reduces porosity, thus increasing the compressive strength [46]. In addition, the availability of alumino-silicate minerals has also been known to help increase the development of strength, which is activated by the alkaline nature of the mine waste used in the brick fabrication. The difference with the normal brick (without the addition of mine waste) was that the performance of the gold mine waste bricks was supplemented by the availability of more $\mathrm{Mg}$ and Fe silicates, originating from the mine waste and Ca-containing cement matrix, which provides greater capacity for carbonation to occur. The alkaline nature of the mine waste also provided greater capacity for $\mathrm{CO}_{2}$ adsorption [68,69]. MgO-containing material has been a preferred sorbent for $\mathrm{CO}_{2}$ capture as they offer promising capacity such as due to high surface area, large pore size and large pore volume, which provides more active sites for adsorption [70,71]. MgO's unique features such as its basic surface may induce $\mathrm{CO}_{2}$ uptake performance. $\mathrm{MgO}$ possesses an advantage in that it helps in the adsorption process, which occurs when acidic $\mathrm{CO}_{2}$ reacts with the basic $\mathrm{Mg}^{2+}$ sites 
and forms carbonate species such as carbonate and bicarbonate [1]. The Fe oxide mineral is one of the metal-bearing oxides other than $\mathrm{Mg}$ and $\mathrm{Ca}$ silicates that can undergo a chemical reaction with $\mathrm{CO}_{2}$ to form stable solid carbonates through the process of mineral carbonation [33-35].

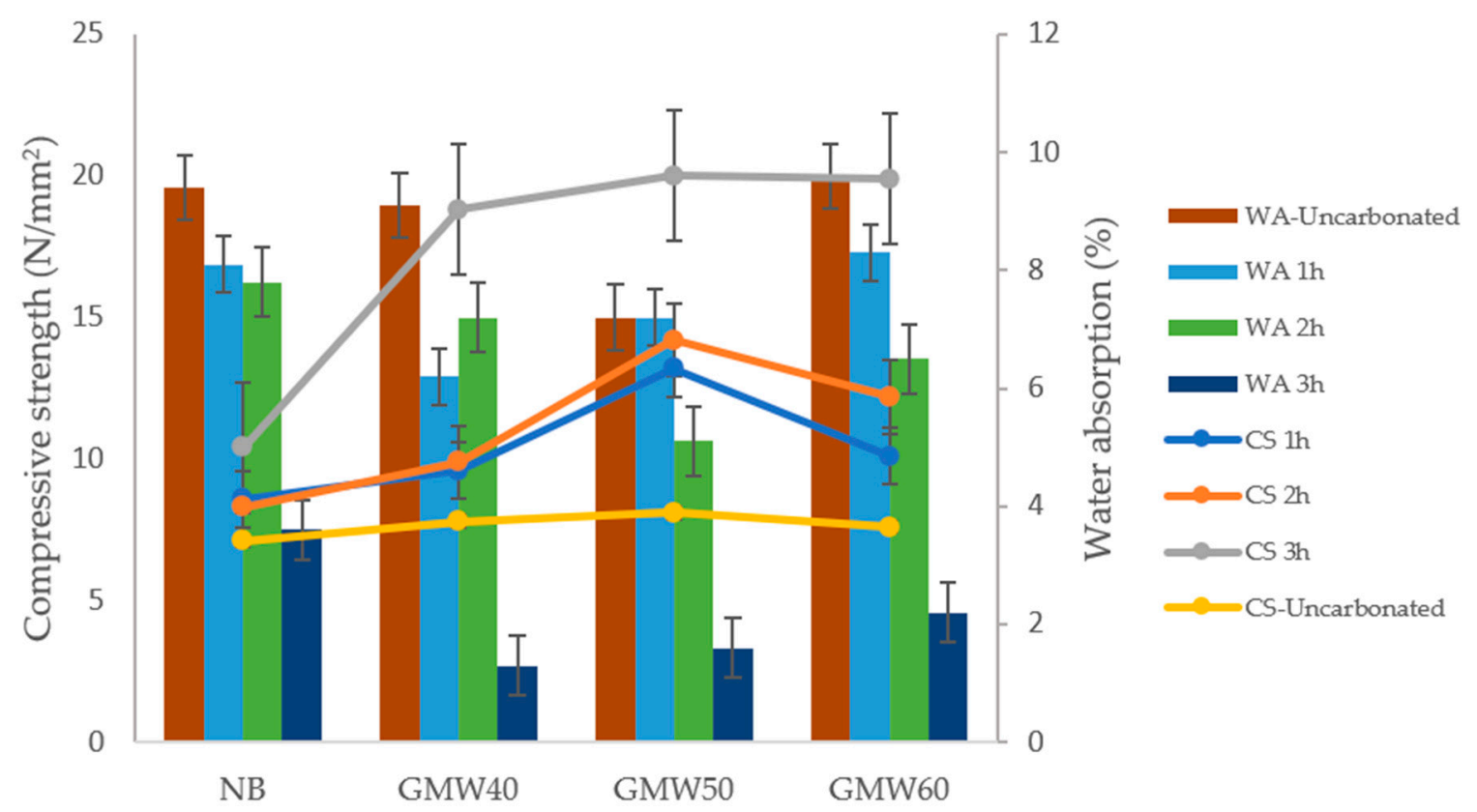

Figure 6. Effect of carbonation time on compressive strength and water absorption of bricks at different mine waste ratios.

In terms of $\mathrm{CO}_{2}$ uptake (Figure 7), as anticipated, longer carbonation time resulted in greater $\mathrm{CO}_{2}$ uptake, such that the uptake capacity was notably high at $3 \mathrm{~h}$ carbonation time (the difference is significantly high at $p<0.01$ compared to $1 \mathrm{~h}$ and $2 \mathrm{~h}$ carbonation, respectively). The $\mathrm{CO}_{2}$ uptake increased as with the increase in mine waste ratio in bricks. Even though a greater amount of sequestered $\mathrm{CO}_{2}$ and higher strength of brick were observed at a greater proportion of gold mine waste, the addition of a higher percentage of waste-oriented material is not always preferable due to some engineering restrictions and requirements. Hence, the proportion is limited to only $60 \%$.

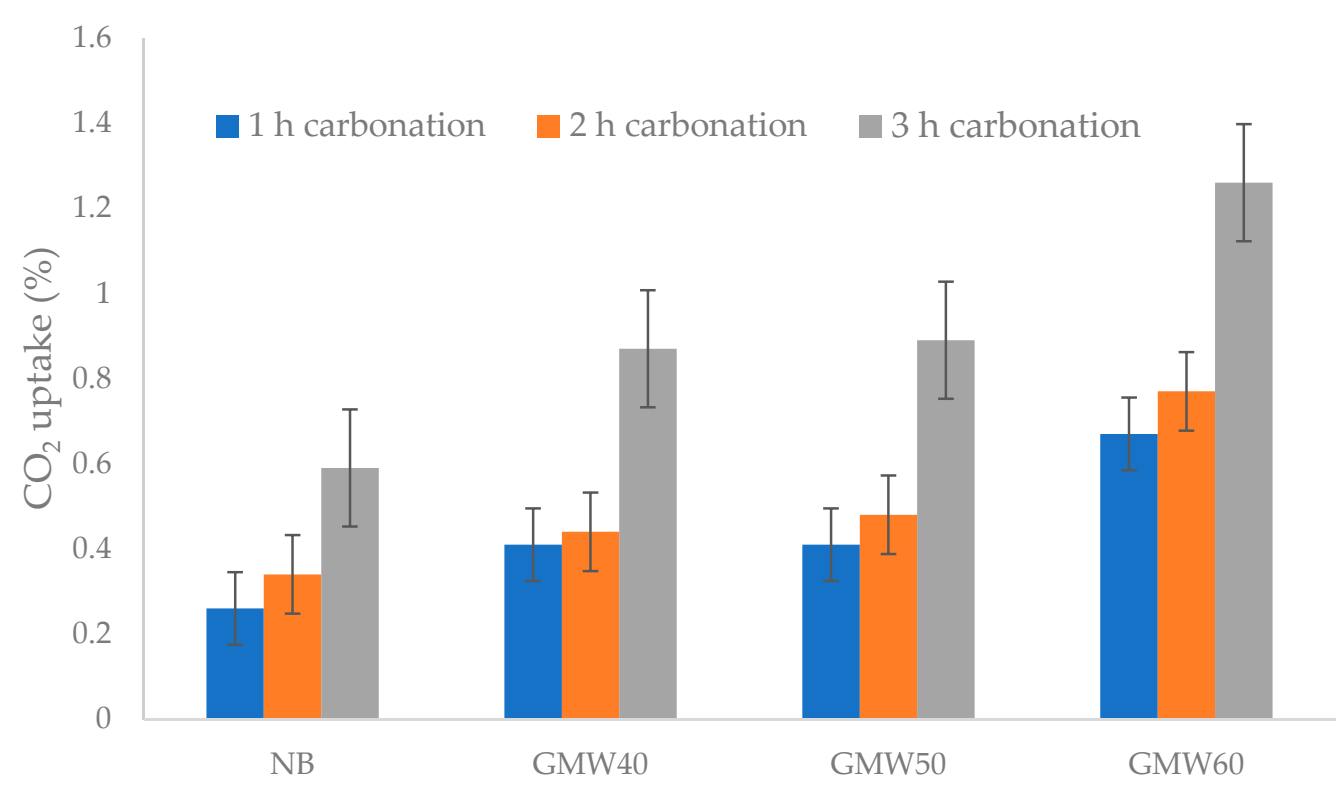

Figure 7. $\mathrm{CO}_{2}$ uptake of mine waste bricks at different carbonation times. 
The carbonation reaction can be evidenced from the compositional changes of the aggregates in bricks with 50\% partial replacement with gold mine waste (Table 7). Despite being initially absent in the mine waste, $\mathrm{CaO}$ was derived from the Portland cement used in brick making. Upon reaction with $\mathrm{CO}_{2}$, i.e., at 1 and $3 \mathrm{~h}$ carbonation, the percentage of $\mathrm{CaO}, \mathrm{Fe}_{2} \mathrm{O}_{3}$ and $\mathrm{MgO}$ were increased, which implies their reaction with $\mathrm{CO}_{2}$ in the formation of carbonate minerals. These oxide components are the reactive minerals in the mine waste, which reacted with $\mathrm{CO}_{2}$ to form carbonate minerals such as $\mathrm{CaCO}_{3}, \mathrm{FeCO}_{3}$ and $\mathrm{MgCO}_{3}[35,72,73]$. While silica was abundantly present in the mine waste, it reacted with $\mathrm{CaO}$, thus forming calcium silicate, which can further react with $\mathrm{CO}_{2}$. It can be seen that after 1 to $3 \mathrm{~h}$ of $\mathrm{CO}_{2}$ exposure, $\mathrm{SiO}_{2}$ content was reduced, suggesting that silicate compound was utilized during the carbonation reaction. On the other hand, $\mathrm{Fe}_{2} \mathrm{O}_{3}$ has been shown to have active sites on the surface that reacted with $\mathrm{CO}_{2}$ gaseous and is a desirable sorbent, as they can be regenerated and carbonated many times [35].

Clearly, after carbonation, the composition of the aggregate is dominated by $\mathrm{CaCO}_{3}$ as indicated by the relatively high percentage of $\mathrm{CaO}$ compared to other oxide components. The formation of $\mathrm{CaCO}_{3}$ is essential in that it helped improve material strength development and properties of a binder system in brick making. This is because the carbonated products, i.e., $\mathrm{CaCO}_{3}$ particles, have the capacity for filling the pores, thus refining the pore structure of the material [46]. Similarly, the carbonation also led to a reduction in total porosity that improved its strength [43].

XRD patterns of the samples were obtained as illustrated in Figure 8. In the uncarbonated brick, i.e., standard curing, obvious diffractogram peaks were noticeable for calcium hydroxide $\left(\mathrm{Ca}(\mathrm{OH})_{2}\right)$, alite $\left(\mathrm{C}_{3} \mathrm{~S}\right)$, belite $\left(\mathrm{C}_{2} \mathrm{~S}\right)$ and ettringite $(\mathrm{AFt})$, while weak peaks of calcite $\left(\mathrm{CaCO}_{3}\right)$ were also seen. Alite and belite are tricalcium silicate and dicalcium silicate, respectively, which are compounds in Portland cement-based materials. The compounds can make the cement phases more reactive when mixed with water, and they react to form calcium silicate hydrate (C-S-H), which is the primary binding material in cement paste. Ettringite, $(\mathrm{CaO})_{6}\left(\mathrm{Al}_{2} \mathrm{O}_{3}\right)\left(\mathrm{SO}_{3}\right)_{3} \cdot 32 \mathrm{H}_{2} \mathrm{O}$, is a hexacalcium aluminate trisulfate hydrate, which is a hydration product that results from the reaction of calcium aluminate and calcium sulfate. In contrast, for the carbonated samples ( $1 \mathrm{~h}$ and $3 \mathrm{~h}$ carbonation), it is apparent that strong peaks of calcite were observed, while the peaks for $\mathrm{Ca}(\mathrm{OH})_{2}$ were reduced. Calcite might be formed owing to the carbonation of Portlandite $\left(\mathrm{Ca}(\mathrm{OH})_{2}\right)$ in the mixture during the curing process [44]. This implies that $\mathrm{Ca}(\mathrm{OH})_{2}$ was transformed into $\mathrm{CaCO}_{3}$ as a result of the carbonation curing, forming a more densified structure typically associated with lower porosity $[44,46]$. Disappeared or reduced peaks for ettringite and $\mathrm{C}_{3} \mathrm{~S} / \mathrm{C}_{3} \mathrm{~S}$ can be observed after carbonation, which can be attributed to further hydration and interconnection of the hydration products with calcium carbonate. However, no magnesium carbonates were identified from the XRD, although it is known that $\mathrm{Mg}$ silicates can co-precipitate with calcium ion forming magnesian calcite [74]. This implies that the Ca carbonated product was greatly dominating in the bricks compared to $\mathrm{Mg}$ carbonate which was not evidently seen, although it is known that the role of $\mathrm{MgO}$ in carbonation cannot be ruled out. Therefore, it is likely that $\mathrm{MgO}$ helped more importantly in providing basicity, the condition that is essential to facilitate carbonation.

Further evidence of the carbonation reaction can be seen from the SEM morphology of the specimens (Figure 9). In uncarbonated specimens, the formation of hydration products such as calcium silicate hydrate (C-S-H) and needle-like ettringite (AFt) can be seen due to the hydration of calcium silicate mineral in the specimen (Figure 9a). The hydration products agglomerated loosely and form a porous microstructure. However, the clusters seen may be associated with calcium carbonate, as identified from the XRD analysis (Figure 8), such that the uncarbonated sample also contains calcite, although the amount is relatively minimal compared to the carbonated samples. After $3 \mathrm{~h}$ carbonation, a more densified microstructure can be seen, with interconnected calcium carbonate being formed (Figure 9b). Ettringite was no longer clearly seen, which was also supported by the XRD patterns. A more clear formation of crystalline, irregular shape of calcium carbonate can 
be seen in Figure 9c, indicating the formation of the carbonated products. The carbonated products comprise a large number of calcium carbonate crystals interconnected with the hydration products, forming a densified structure [75]. It is clear that the formation of calcium carbonate, which is the dominant product of the carbonation, was seen.

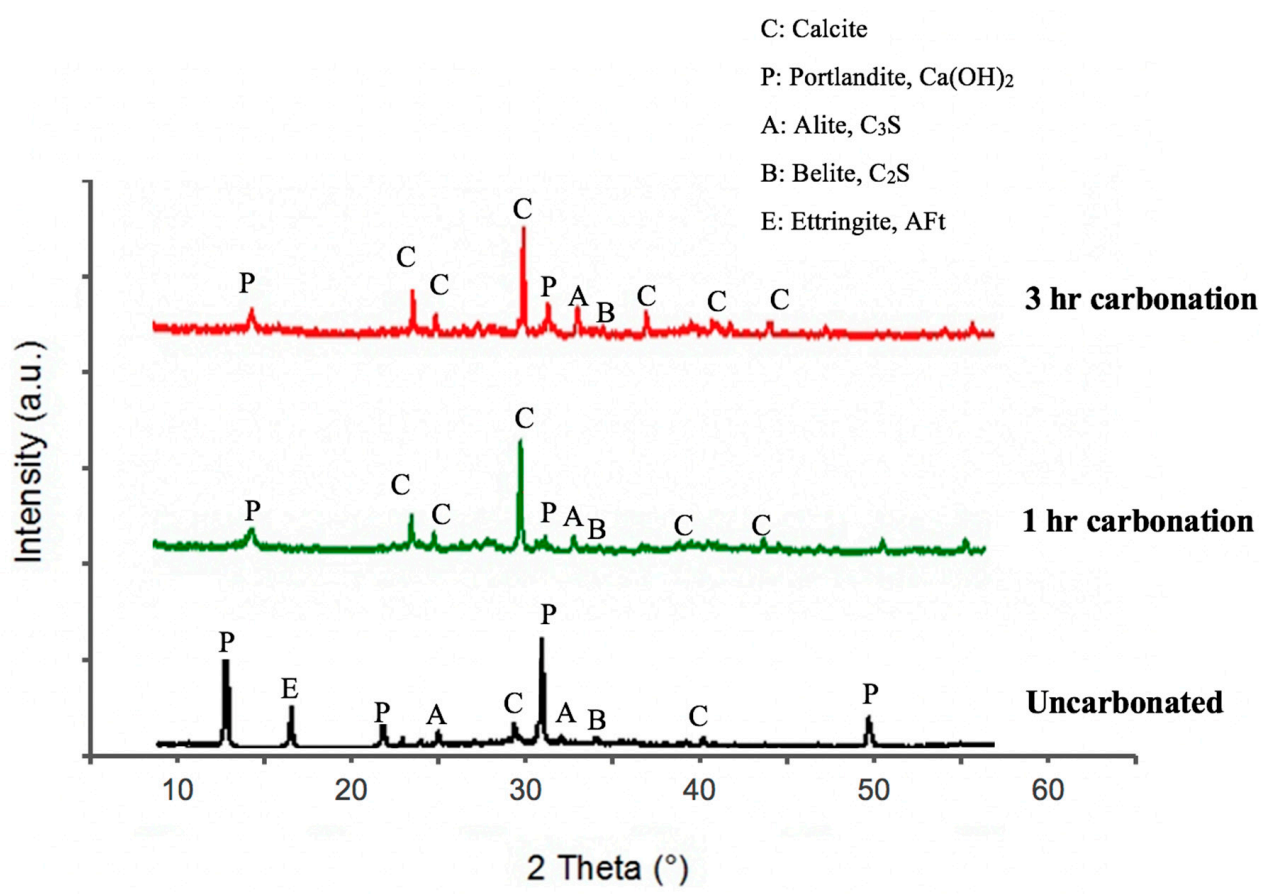

Figure 8. XRD patterns of uncarbonated and carbonated brick specimens.
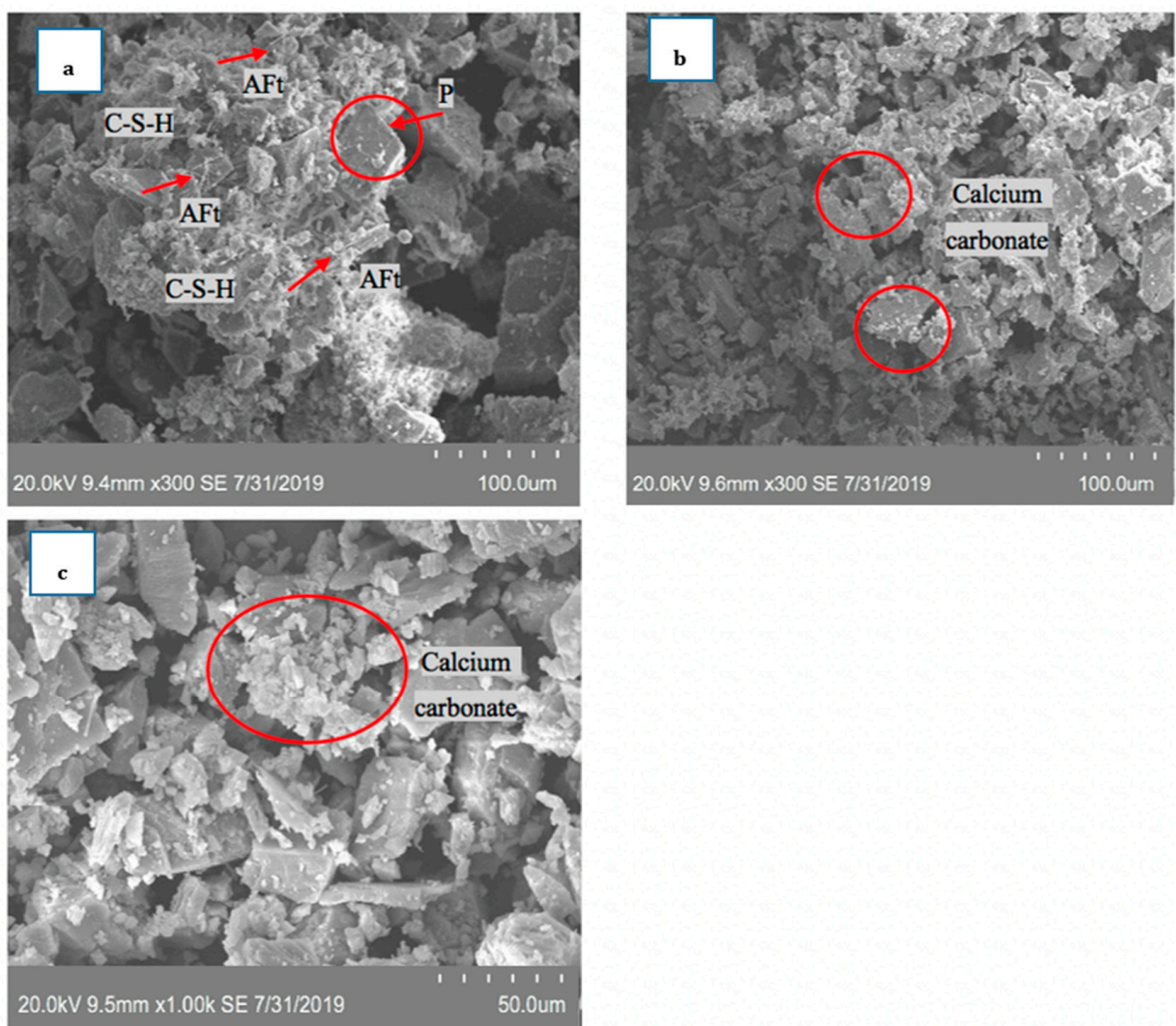

Figure 9. SEM morphology of aggregates in brick specimens: (a) uncarbonated brick, (b) $3 \mathrm{~h}$ carbonated brick at $\times 300$ magnification, and (c) 3 h carbonated brick at $\times 1.00 \mathrm{k}$ magnification. 
The findings from this study are comparable to those of other studies on different types and proportions of waste materials as raw substances in brick making. The strengths attained for brick in this study, i.e., $7.8-20.0 \mathrm{~N} / \mathrm{mm}^{2}$, are in line with other cement-based products partially made of waste materials such as fly ash $\left(6.75 \mathrm{~N} / \mathrm{mm}^{2}\right)$ [76], 10-30 wt.\% palm oil fuel ash (15-22.5 N/ mm²) [77], $50 \mathrm{wt}$.\% iron ore tailings (33-36 N/mm²) [78], 4-10 wt.\% copper mine tailings (5-35 N/ mm ${ }^{2}$ ) [79], 25-90 wt.\% gold mine tailings (3-20 N/mm ${ }^{2}$ [80] and 25-35 wt.\% cement kiln dust (12.5-16.5 N/ $\mathrm{mm}^{2}$ ) [81], among others, but are relatively low compared to the use of 35-70 wt.\% recycled brick aggregates (43-59 N/ $\left.\mathrm{mm}^{2}\right)$ [82]. In terms of $\mathrm{CO}_{2}$ sequestration performance, the findings are also comparable with some other studies, such as the improvement in material strength after carbonation, e.g., with 2-18 h carbonation time [45], $4 \mathrm{~h}$ carbonation [46] and 1-14 d carbonation curing [44,83]. Application-wise, various cement-based products have been studied as potential $\mathrm{CO}_{2}$ sink for carbon capture and storage, e.g., concrete [44,83], cement-bonded fibreboards [45], cement boards [12], concrete blocks [42,84] and cement mortar [84]. It has been found from the previous studies that the $\mathrm{CO}_{2}$ uptake of the carbonated products were $2-3.5 \%$ (concrete) [85], 9.8-14.1\% (concrete) [44], 20\% (cement fibreboards) [45], 9.4-13.9\% (cement mortar) [46], 24\% (concrete blocks/bricks) [42], while it was between 0.4 and $1.3 \%$ in this study (cement-sand bricks fabricated with carbonation curing at ambient pressure and temperature). The greater $\mathrm{CO}_{2}$ uptakes found in other studies were mostly attributed to accelerated carbonation such as carbonation with exposure at certain temperature ranges, carbonation at a particular $\mathrm{CO}_{2}$ pressure, use of alkali activator, use of couple mineral admixtures and carbonation curing, and other techniques. Therefore, it has been demonstrated that gold mine waste can be used as a partial replacement or supplementary cementitious material that can promote carbonation reaction, thus stimulating its potential for long-term $\mathrm{CO}_{2}$ capture. The important characteristics of the mine waste potentially useful for carbon sequestration have been investigated, and its utilization as a carbon storage product has been highlighted.

\section{Conclusions}

This study has discovered the potential of gold mining waste for $\mathrm{CO}_{2}$ sequestration and its utilization for long-term carbon storage in cementitious material. Mine wastes' characterization has been performed based on their mineralogical and chemical composition to identify the potential for sequestering atmospheric $\mathrm{CO}_{2}$. Overall, the mine waste samples, which included waste rocks, soil, sediment and sludge, were composed of potential minerals for carbonation such as Mg-Fe silicates, mainly of muscovite and illite, alongside mineral quartz and kaolinite (major mineral phases). Other silicate minerals included chlorite-serpentine, aerinite, albite and stilpnomelane (moderate/minor phases). $\mathrm{SiO}_{2}$ and $\mathrm{Al}_{2} \mathrm{O}_{3}$ were found to be relatively higher than other oxide minerals, suggesting that the mine waste samples were of aluminosilicate material. The mine wastes were found to contain important oxide minerals known to be essential for mineral carbonation. The presence of $\mathrm{MgO}$ and $\mathrm{Fe}_{2} \mathrm{O}_{3}$ was associated with minerals muscovite, illite and aerinite, whilst $\mathrm{Al}_{2} \mathrm{O}_{3}$ was attributable to minerals kaolinite, chlorite-serpentine, muscovite, illite and aerinite. The mine waste samples can be categorized as highly pozzolanic as they contain a great amount of pozzolanic oxides of $\mathrm{SiO}_{2}, \mathrm{Al}_{2} \mathrm{O}_{3}$ and $\mathrm{Fe}_{2} \mathrm{O}_{3}$. Clearly, the chemical and mineral properties of the mine waste samples were of great importance such that they influenced the pozzolanic behavior as well as the potential for carbon sequestration.

In terms of mine waste utilization for carbon storage, it has been used as a partial replacement for cement in brick making and as an agent for $\mathrm{CO}_{2}$ capture in the product. The pozzolanic behavior of the mine waste has a great role in improving the strength properties of the brick product. Carbonation reaction components such as $\mathrm{CaO}$ and $\mathrm{MgO}$ produced carbonate minerals that served as an additional binder, which has increased the strength of the cement-based material. The availability of storage capacity of the mine waste gives it potential for carbon capture and storage. It has been estimated that $\mathrm{CO}_{2}$ uptake of the product was between 0.24 and $0.57 \%$ for the bricks containing $40-60 \%$ of gold mine 
waste. The resulting amount of sequestered $\mathrm{CO}_{2}$ of the mine waste bricks was estimated to be between 7.2 and $17.1 \mathrm{~g} \mathrm{CO}_{2} /$ brick product. Greater performance was observed for carbonated bricks compared to the uncarbonated bricks, i.e., compressive strength notably increased, while water adsorption greatly decreased as carbonation time was increased up to $3 \mathrm{~h}$. Similarly, greater $\mathrm{CO}_{2}$ uptake was observed at $3 \mathrm{~h}$ carbonation curing. The carbonation reaction can be evidenced through the compositional changes of the major oxide elements such as increased percentage of $\mathrm{CaO}, \mathrm{Fe}_{2} \mathrm{O}_{3}$ and $\mathrm{MgO}$ and reduced $\mathrm{SiO}_{2}$ content. Further evidence was obtained from the XRD patterns that strong peaks of calcite were observed, while the peaks for $\mathrm{Ca}(\mathrm{OH})_{2}$ were reduced for carbonated bricks. This was supported by a more densified, crystalline and interconnected microstructure of material, which implies the formation of calcium carbonate due to the carbonation reactions. It is worth noting that this work is limited to only a short exposure time for carbonation, while it is known that a longer carbonation time may influence the carbonated product. While this study utilized pure $\mathrm{CO}_{2}$ gas for carbonation curing, it should be noted that carbonation of cement-based product in flue gas may result in a lower carbonation efficiency. Future research may look into a wider range of mine waste types, waste proportion and carbonation times in determining the effect of the carbonation process while adopting accelerated carbonation to improve the uptake of $\mathrm{CO}_{2}$. Various other applications for $\mathrm{CO}_{2}$ storage may be applied to explore the utilization part of the captured carbon.

Therefore, it has been observed that gold mine waste can be a potential feedstock for mineral carbonation given its capacity for $\mathrm{CO}_{2}$ capture and storage. Its utilization as a supplementary cementitious material would be advantageous in that it minimizes the use of manufactured cement for the construction industry while using waste materials. The carbonated product provides an option for permanent and long-term storage of $\mathrm{CO}_{2}$, which is a beneficial application in response to sustainable climate mitigation strategies.

Author Contributions: S.N.M.S.H. performed the experiments, analyzed data and wrote the paper under the supervision of F.M.K.; F.M.K. revised the paper and provided funding. N.N.N.D., M.A.S., F.M.-Y. and Z.H.A. helped in conceptualization, performing the experiments, data analysis, validation and funding. All authors have read and agreed to the published version of the manuscript.

Funding: This research was funded by Ministry of Higher Education Malaysia (MOHE), grant number KPM FRGS/1/2018/TK10/UPM/02/7 (FRGS 5540081) and Universiti Putra Malaysia, grant number IPS 9574900.

Institutional Review Board Statement: Not applicable.

Informed Consent Statement: Not applicable.

Data Availability Statement: The data presented in this study are available on request from the corresponding author. The data are not publicly available due to data that forms part of an on-going study.

Acknowledgments: The authors would like to appreciate the manager of the iron mine in Jerantut, Pahang, Malaysia, for his kind permission to take iron mine waste samples for research purposes. The authors also wish to thank the laboratory staff at the Centre for Research and Instrumentation (CRIM), Universiti Kebangsaan Malaysia, Bangi, Malaysia, and Department of Chemical and Environmental Engineering, Faculty of Engineering, Universiti Putra Malaysia, Serdang, Malaysia, for providing technical assistance and instruments for laboratory analysis.

Conflicts of Interest: The authors declare no conflict of interest. The founding sponsors had no role in the collection, analysis, or interpretation of data; in the writing of the manuscript; or in the decision to publish the results.

\section{References}

1. Ruhaimi, A.H.; Aziz, M.A.A.; Jalil, A.A. Magnesium oxide-based adsorbents for carbon dioxide capture: Current progress and future opportunities. J. CO2 Util. 2021, 43, 101357. [CrossRef]

2. IEA. World Energy Outlook; International Energy Agency (IEA): Paris, France, 2019; ISBN 9789264973008.

3. IEAGHG. CO2 Capture in the Cement Industry; IEAGHG: Cheltenham, UK, 2008. 
4. IPCC. Global Warming of 1.5 C: An IPCC Special Report on the Impacts of Global Warming of 1.5 C above Pre-Industrial Levels and Related Global Greenhouse Gas Emission Pathways, in the Context of Strengthening the Global Response to the Threat of Climate Change, Sustainable Development, and Efforts to Eradicate Poverty; Masson-Delmotte, V., Zhai, P., Pörtner, H.O., Roberts, D., Skea, J., Shukla, P.R., Pirani, A., Moufouma-Okia, W., Péan, C., Pidcock, R., et al., Eds.; IPCC: Geneva, Switzerland, 2018.

5. Zhang, D.; Song, J. Mechanisms for geological carbon sequestration. Procedia IUTAm 2014, 10, 319-327. [CrossRef]

6. Arce, G.L.A.F.; Neto, T.G.S.; Ávila, I.; Luna, C.M.R.; dos Santos, J.C.; Carvalho, J.A. Influence of physicochemical properties of Brazilian serpentinites on the leaching process for indirect $\mathrm{CO}_{2}$ mineral carbonation. Hydrometallurgy 2017, 169, 142-151. [CrossRef]

7. Gabrielli, P.; Gazzani, M.; Mazzotti, M. The role of carbon capture and utilization, carbon capture and storage, and biomass to enable a net-zero- $\mathrm{CO}_{2}$ emissions chemical industry. Ind. Eng. Chem. Res. 2020, 59, 7033-7045. [CrossRef]

8. Hills, C.D.; Tripathi, N.; Carey, P.J. Mineralization technology for carbon capture, utilization, and storage. Front. Energy Res. 2020, 8, 142. [CrossRef]

9. Washbourne, C.L.; Lopez-Capel, E.; Renforth, P.; Ascough, P.L.; Manning, D.A.C. Rapid removal of atmospheric $\mathrm{CO}_{2}$ by urban soils. Environ. Sci. Technol. 2015, 49, 5434-5440. [CrossRef]

10. Jorat, M.E.; Kolosz, B.W.; Goddard, M.A.; Sohi, S.P.; Akgun, N.; Dissanayake, D.; Manning, D.A.C. Geotechnical requirements for capturing $\mathrm{CO}_{2}$ through highways land. Int. J. GEOMATE 2017, 13, 22-27. [CrossRef]

11. Olajire, A.A. A review of mineral carbonation technology in sequestration of $\mathrm{CO}_{2}$. J. Pet. Sci. Eng. 2013, 109, 364-392. [CrossRef]

12. Power, I.M.; Dipple, G.M.; Francis, P.S. Assessing the carbon sequestration potential of magnesium oxychloride cement building materials. Cem. Concr. Compos. 2017, 78, 97-107. [CrossRef]

13. Ibrahim, M.H.; El-Naas, M.H.; Benamor, A.; Al-Sobhi, S.S.; Zhang, Z. Carbon mineralization by reaction with steel-making waste: A review. Processes 2019, 7, 115. [CrossRef]

14. Plaza, M.G.; Martínez, S.; Rubiera, F. $\mathrm{CO}_{2}$ Capture, Use, and Storage in the Cement Industry: State of the Art and Expectations. Energies 2020, 13, 5692. [CrossRef]

15. Stopic, S.; Dertmann, C.; Modolo, G.; Kegler, P.; Neumeier, S.; Kremer, D.; Wotruba, H.; Etzold, S.; Telle, R.; Rosani, D.; et al. Synthesis of magnesium carbonate via carbonation under high pressure in an autoclave. Metals 2018, 8, 993. [CrossRef]

16. Jorat, M.E.; Goddard, M.A.; Manning, P.; Lau, H.K.; Ngeow, S.; Sohi, S.P.; Manning, D.A.C. Passive $\mathrm{CO}_{2}$ removal in urban soils: Evidence from brownfield sites. Sci. Total Environ. 2020, 703, 135573. [CrossRef] [PubMed]

17. Hitch, M.; Ballantyne, S.M.; Hindle, S.R. Revaluing mine waste rock for carbon capture and storage. Int. J. Min. Reclam. Environ. 2010, 24, 64-69. [CrossRef]

18. Kusin, F.M.; Awang, N.H.C.; Hasan, S.N.M.S.; Rahim, H.A.A.; Jusop, S.; Kim, K.W. Geoecological evaluation of mineral, major and trace elemental composition in waste rocks, soils and sediments of a gold mining area and potential associated risks. Catena 2019, 183, 104229. [CrossRef]

19. Power, I.M.; McCutcheon, J.; Harrison, A.L.; Wilson, S.A.; Dipple, G.M.; Kelly, S.; Southam, C.; Southam, G. Strategizing Carbon-Neutral Mines: A Case for Pilot Projects. Minerals 2014, 4, 399-436. [CrossRef]

20. Wilson, S.A.; Dipple, G.M.; Power, I.M.; Thom, J.M.; Anderson, R.G.; Raudsepp, M.; Gabites, J.E.; Southam, G. Carbon Dioxide Fixation within Mine Wastes of Ultramafic-Hosted Ore Deposits: Examples from the Clinton Creek and Cassiar Chrysotile Deposits Canada. Econ. Geol. 2009, 104, 95-112. [CrossRef]

21. Li, J.; Hitch, M. Carbon dioxide adsorption isotherm study on mine waste for integrated $\mathrm{CO}_{2}$ capture and sequestration processes. Powder Technol. 2015, 291, 408-413. [CrossRef]

22. Sanna, A.; Uibu, M.; Caramanna, G.; Kuusikb, R.; Maroto-Valerac, M.M. A review of mineral carbonation technologies to sequester $\mathrm{CO}_{2}$. Chem. Soc. Rev. 2014, 43, 8049-8080. [CrossRef] [PubMed]

23. Bobicki, E.R.; Liu, Q.; Xu, Z.; Zeng, H. Carbon capture and storage using alkaline industrial wastes. Prog. Energy Combust. Sci. 2012, 38, 302-320. [CrossRef]

24. Pan, S.Y.; Chang, E.E.; Chiang, P.C. $\mathrm{CO}_{2}$ capture by accelerated carbonation of alkaline wastes: A review on its principles and applications. Aerosol Air Qual. Res. 2012, 12, 770-791. [CrossRef]

25. Gras, A.; Beaudoin, G.; Molson, J.; Plante, B.; Bussière, B.; Lemieux, J.M.; Dupont, P.P. Isotopic evidence of passive mineral carbonation in mine wastes from the Dumont Nickel Project (Abitibi, Quebec). Int. J. Greenh. Gas Control 2017, 60, 10-23. [CrossRef]

26. Guo, Y.; Tan, C.; Wang, P.; Sun, J.; Li, W.; Zhao, C.; Lu, P. Magnesium-based basic mixtures derived from earth-abundant natural minerals for $\mathrm{CO}_{2}$ capture in simulated flue gas. Fuel 2019, 243, 298-305. [CrossRef]

27. Herzog, H. Carbon Sequestration via Mineral Carbonation: Overview and Assessment; MIT Laboratory for Energy and the Environment: Cambridge, MA, USA, 2002.

28. Jacobs, A.D.; Hitch, M. Experimental mineral carbonation: Approaches to accelerate $\mathrm{CO}_{2}$ sequestration in mine waste materials. Int. J. Min. Reclam. Environ. 2011, 25, 321-331. [CrossRef]

29. Manning, D.A.C.; Renforth, P.; Lopez-Capel, E.; Robertson, S.; Ghazireh, N. Carbonate precipitation in artificial soils produced from basaltic quarry fines and composts: An opportunity for passive carbon sequestration. Int. J. Greenh. Gas Conrol 2013, 17, 309-317. [CrossRef]

30. Lackner, K.S.; Wendt, C.H.; Butt, D.P.; Joyce, E.L.; Sharps, D.H. Carbon dioxide disposal in carbonate minerals. Energy 1995, 20, 1153-1170. [CrossRef] 
31. Vogeli, J.; Reid, D.L.; Becker, M.; Broadhurst, J.; Franzidis, J.P. Investigation of the potential for mineral carbonation of PGM tailings in South Africa. Miner. Eng. 2011, 24, 1348-1356. [CrossRef]

32. Hasan, S.N.M.S.; Kusin, F.M.; Shamshuddin, J.; Yusuff, F.M. Potential of soil, sludge and sediment for mineral carbonation process in Selinsing gold mine, Malaysia. Minerals 2018, 8, 257. [CrossRef]

33. Azdarpour, A.; Karaei, A.K.; Hamidi, H.; Mohammadian, E.; Honarvar, B. $\mathrm{CO}_{2}$ sequestration through direct aqueous mineral carbonation of red gypsum. Petroleum 2018, 4, 1-10. [CrossRef]

34. Mendoza, E.Y.M.; Santos, A.S.; López, E.V.; Drozd, V.; Durygin, A.; Chen, J.; Saxena, S.K. Siderite Formation by Mechanochemical and High Pressure-High Temperature Processes for $\mathrm{CO}_{2}$ Capture Using Iron Ore as the Initial Sorbent. Processes $2019,7,735$. [CrossRef]

35. Mendoza, E.Y.M.; Santos, A.S.; López, E.V.; Drozd, V.; Durygin, A.; Chen, J.; Saxena, S.K. Iron oxides as efficient sorbents for CO 2 capture. J. Matter. Res. Technol. 2019, 8, 2944-2956. [CrossRef]

36. Assima, G.P.; Larachi, F.; Molson, J.; Beaudoin, G. Impact of temperature and oxygen availability on the dynamics of ambient $\mathrm{CO}_{2}$ mineral sequestration by nickel mining residues. Chem. Eng. J. 2014, 240, 394-403. [CrossRef]

37. IEA. Technology Roadmap Low-Carbon Transition in the Cement Industry; IEA: Paris, France, 2018.

38. Andrew, R.M. Global $\mathrm{CO}_{2}$ emissions from cement production. Earth Syst. Sci. Data 2018, 10, 195-217. [CrossRef]

39. GCCA. GCCA Launches 'Innovandi-The Global Cement and Concrete Research Network'. Singapore, 10 October 2019; Global Cement and Concrete Association: London, UK, 2019.

40. Hepburn, C.; Adlen, E.; Beddington, J.; Carter, E.A.; Fuss, S.; Mac Dowell, N.; Minx, J.C.; Smith, P.; Williams, C.K. The technological and economic prospects for $\mathrm{CO}_{2}$ utilization and removal. Nature 2019, 575, 87-97. [CrossRef]

41. Tsivilis, S.; Batis, G.; Chaniotakis, E.; Grigoriadis, G.; Theodossis, D. Properties and behavior of limestone cement concrete and mortar. Cem. Concr. Res. 2000, 30, 1679-1683. [CrossRef]

42. El-Hassan, H.; Shao, Y. Carbon Storage through Concrete Block Carbonation Curing. J. Clean Energy Technol. $2014,2,287-291$. [CrossRef]

43. Ashraf, W. Carbonation of cement-based materials: Challenges and opportunities. Constr. Build. Mater. 2016, 120, 558-570. [CrossRef]

44. Mo, L.; Hao, Y.; Liu, Y.; Wang, F.; Deng, M. Preparation of calcium carbonate binders via $\mathrm{CO}_{2}$ activation of magnesium slag. Cem. Concr. Res. 2019, 121, 81-90. [CrossRef]

45. He, Z.; Jia, Y.; Wang, S.; Mahoutian, M.; Shao, Y. Maximizing $\mathrm{CO}_{2}$ sequestration in cement-bonded fiberboards through carbonation curing. Constr. Build. Mater. 2019, 213, 51-60. [CrossRef]

46. Qin, L.; Gao, X.; Chen, T. Influence of mineral admixtures on carbonation curing of cement paste. Constr. Build. Mater. 2019, 212, 653-662. [CrossRef]

47. Kusin, F.M.; Hasan, S.N.M.S.; Hassim, M.A.; Molahid, V.L.M. Mineral carbonation of sedimentary mine waste for carbon sequestration and potential reutilization as cementitious material. Environ. Sci. Pollut. Res. 2020, 27, 12767-12780. [CrossRef]

48. Mohd-Isha, N.S.; Kusin, F.M.; Kamal, N.M.A.; Hasan, S.N.M.S.; Molahid, V.L.M. Geochemical and mineralogical assessment of sedimentary limestone mine waste and potential for mineral carbonation. Environ. Geochem. Health 2021, 43, 2065-2080. [CrossRef] [PubMed]

49. Snowden. Selinsing Gold Sulphide Project-NI 43-101 Technical Report; Project Number AU10173; Snowden: Perth, Australia, 2019 ; p. 357.

50. Makoundi, C.; Zaw, K.; Large, R.R.; Meffre, S.; Lai, C.K.; Hoe, T.G. Geology, geochemistry and metallogenesis of the Selinsing gold deposit, Central Malaysia. Gondwana Res. 2013, 26, 241-261. [CrossRef]

51. Álvarez, R.; Ordóñez, R.; Pérez, A.; Miguel, E.D.; Charlesworth, S. Mineralogical and environmental features of the asturian copper mining district (Spain): A review. Eng. Geol. 2018, 243, 206-217. [CrossRef]

52. Jusop, S. Methods in Soil Mineralogy; Universiti Putra Malaysia Press: Selangor, Malaysia, 2011.

53. Malaysian Standard MS 76: 1972. Specification for Bricks and Blocks of Fired Brickearth, Clay or Shale. Part 2: Metric Units; Standards and Industrial Research Institute of Malaysia: Selangor, Malaysia, 1972.

54. Rivai, T.A.; Yonezu, K.; Syafrizal; Watanabe, K. Mineralogy and geochemistry of host rocks and orebodies at the Anjing Hitam prospect (Dairi, North Sumatera, Indonesia) and their environmental implications. Evergreen 2019, 6, 18-28. [CrossRef]

55. Hasan, S.N.M.S.; Kusin, F.M.; Shamshuddin, J.; Yusuff, F.M. The mineralogy and chemical properties of sedimentary waste rocks with carbon sequestration potential at Selinsing Gold Mine, Pahang. Pertanika J. Sci. Technol. 2019, 27, 1005-1012.

56. Busch, A.; Bertier, P.; Gensterblum, Y.; Rother, G.; Spiers, C.J.; Zhang, M.; Wentinck, H.M. On sorption and swelling of $\mathrm{CO}_{2}$ in clays. Geomech. Geophys. Geo Energy Geo Resour. 2016, 2, 111-130. [CrossRef]

57. Chouikhi, N.; Cecilia, J.A.; Vilarrasa-García, E.; Besghaier, S.; Chlendi, M.; Duro, F.I.F.; Castellon, E.R.; Bagane, M. CO 2 Adsorption of Materials Synthesized from Clay Minerals: A Review. Minerals 2019, 9, 514. [CrossRef]

58. Steinour, H.H. Some effects of carbon dioxide on mortars and concrete-discussion. J. Am. Concr. Inst. 1959, 30, 905-907. [CrossRef]

59. Daud, N.N.N.; Muhammed, A.S.; Md-Yusoff, Z. Geotechnical assessment of palm oil fuel ash (POFA) mixed with granite residual soil for hydraulic barrier purposes. Malays. J. Civil Eng. 2016, 28, 1-9. [CrossRef]

60. Luukkonen, T.; Heponiemi, A.; Runtti, H.; Pesonen, J.; Yliniemi, J.; Lassi, U. Application of alkali-activated materials for water and wastewater treatment: A review. Rev. Environ. Sci. Biotechnol. 2019, 18, 271-297. [CrossRef] 
61. Hasan, S.N.M.S.; Kusin, F.M. Potential of mining waste from metallic mineral industry for carbon sequestration. In Proceedings of the International Conference on Process Engineering and Advanced Materials (ICPEAM2018), Kuala Lumpur, Malaysia, 13-14 August 2018; Volume 458, p. 012013.

62. Walker, R.; Pavia, S. Physical properties and reactivity of pozzolans, and their influence on the properties of lime-pozzolan pastes. Mater. Struct. 2011, 44, 1139-1150. [CrossRef]

63. Resoli, N.; Neuwald, O.A.; Zattera, A.J.; Piazza, D.; Kunst, S.R.; Birriel, E.J. Effect of addition of clay minerals on the properties of epoxy/polyester powder coatings. Polimeros 2018, 28, 355-367. [CrossRef]

64. Hassouta, L.; Buatier, M.D.; Potdevin, J.L.; Liewig, N. Clay diagenesis in the sandstone reservoir of the Ellon Field (Alwyn, North Sea). Clays Clay Miner. 1999, 47, 269-285. [CrossRef]

65. Villa, R.V.D.-L.; Frías, M.; García-Giménez, R.; Martínez-Ramirez, S.; Fernández-Carrasco, L. Chemical and mineral transformations that occur in mine waste and washery rejects during pre-utilization calcination. Int. J. Coal Geol. 2014, 132, 123-130. [CrossRef]

66. Segvic, B.; Benvenuti, A.; Moscariello, A. Illite-smectite-rich clay parageneses from quaternary tunnel valley sediments of the Dutch Southern North Sea-Mineral origin and paleoenvironment implications. Clays Clay Miner. 2016, 64, 608-627. [CrossRef]

67. Malaysian Standards, MS 1933-1: 2007. Methods of Test for Masonry Units; Standards and Industrial Research Institute of Malaysia: Selangor, Malaysia, 2007.

68. Ramli, N.A.A.; Kusin, F.M.; Molahid, V.L.M. Influencing factors of the mineral carbonation process of the iron ore mining waste in sequestering atmospheric carbon dioxide. Sustainability 2021, 13, 1866. [CrossRef]

69. Molahid, V.L.M.; Kusin, F.M.; Kamal, M.N.A.; Hasan, S.N.M.S.; Ramli, N.A.A.; Abdullah, A.M.; Ashaari, Z.H.A. Carbon sequestration of limestone mine waste through mineral carbonation and utilization as supplementary cementitious material. Int. J. Integr. Eng. 2021, 13, 311-320. [CrossRef]

70. Dal-Pozzo, A.; Armutlulu, A.; Rekhtina, M.; Abdala, P.M.; Müller, C.R. $\mathrm{CO}_{2}$ Uptake and Cyclic Stability of $\mathrm{MgO}-\mathrm{Based}$ CO $_{2}$ Sorbents Promoted with Alkali Metal Nitrates and Their Eutectic Mixtures. ACS Appl. Energy Mater. 2019, 2, 1295-1307. [CrossRef]

71. Jin, S.; Bang, G.; Liu, L.; Lee, C.H. Synthesis of mesoporous $\mathrm{MgO}-\mathrm{CeO} 2$ composites with enhanced $\mathrm{CO}_{2}$ capture rate via controlled combustion. Microporous Mesoporous Mater. 2019, 288, 109587. [CrossRef]

72. Xie, H.; Yue, H.; Zhu, J.; Liang, B.; Li, C.; Wang, Y.; Xie, L.; Zhou, X. Scientific and engineering progress in $\mathrm{CO}_{2}$ mineralization using industrial waste and natural minerals. Engineering 2015, 1, 150-157. [CrossRef]

73. Li, P.; Pan, S.Y.; Pei, S.; Lin, Y.J.; Chiang, P.C. Challenges and perspectives on carbon fixation and utilization technologies: An overview. Aerosol Air Qual. Res. 2016, 16, 1327-1344. [CrossRef]

74. Panesar, D.K.; Mo, L. Properties of binary and ternary reactive $\mathrm{MgO}$ mortar blends subjected to $\mathrm{CO}_{2}$ curing. Cem. Concr. Compos. 2013, 38, 40-49. [CrossRef]

75. Hasan, S.N.M.S.; Kusin, F.M.; Hassim, M.A.; Molahid, V.L.M. Incorporation of gold and limestone mining waste materials for carbon capture and storage in bricks. IOP Conf. Ser. Mater. Sci. Eng. 2020, 736, 022046. [CrossRef]

76. Önel, O.; Tanriverdi, M.; Cicek, T. Utilization of Yatagan power plant fly ash in production of building bricks. IOP Conf. Ser. Earth Environ. Sci. 2017, 95, 042012. [CrossRef]

77. Rahman, M.E.; Ong, P.J.; Nabinejad, O.; Islam, S.; Khandoker, N.A.N.; Pakrashi, V.; Shorowordi, K.M. Utilization of blended waste materials in bricks. Technologies 2018, 6, 20. [CrossRef]

78. Kuranchie, F.A.; Shukla, S.K.; Habibi, D.; Mohyeddin, A. Utilisation of iron ore tailings as aggregates in concrete. Cogent Eng. 2015, 2, 1083137. [CrossRef]

79. Ahmari, S.; Zhang, L. Production of eco-friendly bricks from copper mine tailings through geopolymerization. Constr. Build. Mater. 2012, 29, 323-331. [CrossRef]

80. Kiventera, J.; Piekkari, K.; Isteri, V.; Ohenoja, K.; Tanskanen, P.; Illikainen, M. Solidification/stabilization of gold mine tailings using calcium sulfoaluminate-belite cement. J. Clean. Prod. 2019, 239, 118008. [CrossRef]

81. Ahmed, S.A.; Metwally, M.E.A.; Zakey, S.E. Utilizing industrial waste-water as alkali activator in sand-cement kiln dust bricks. Constr. Build. Mater. 2018, 182, 284-289. [CrossRef]

82. Gonzalez, J.S.; Gayarre, F.L.; Pérez, C.L.; Ros, P.S.; López, M.A.S. Influence of recycled brick aggregates on properties of structural concrete for manufacturing precast prestressed beams. Constr. Build. Mater. 2017, 149, 507-514. [CrossRef]

83. Mo, L.; Zhang, F.; Deng, M.; Jin, F.; Al-Tabbaa, A.; Wang, A. Accelerated carbonation and performance of concrete made with steel slag as binding materials and aggregates. Cem. Concr. Compos. 2017, 83, 138e145. [CrossRef]

84. Huang, H.; Wang, T.; Kolosz, B.; Andresen, J.; Garcia, S.; Fang, M.; Maroto-Valer, M.M. Life-cycle assessment of emerging CO 2 mineral carbonation-cured concrete blocks: Comparative analysis of $\mathrm{CO}_{2}$ reduction potential and optimization of environmental impacts. J. Clean. Prod. 2019, 241, 118359. [CrossRef]

85. Kwasny, J.; Basheer, P.A.M.; Russell, M.I.; Doherty, W.; Owens, K.; Ward, N. $\mathrm{CO}_{2}$ Sequestration in Cement-Based Materials during Mixing Process Using Carbonated Water and Gaseous $\mathrm{CO}_{2}$. In Proceedings of the 4th International Conference on the Durability of Concrete Structures (ICDCS), West Lafayette, IN, USA, 24-26 July 2014; Olek, J., Weiss, J., Eds.; Purdue Scholarly Publishing Services: West Lafayette, IN, USA, 2014. 